University of Miami Law School University of Miami School of Law Institutional Repository

Articles

Faculty and Deans

2001

\title{
Complementary Agreements and Compulsory Jurisdiction
}

Bernard H. Oxman

University of Miami School of Law, bhoxman@law.miami.edu

Follow this and additional works at: https://repository.law.miami.edu/fac_articles

Part of the International Law Commons, Jurisdiction Commons, and the Law of the Sea Commons

\section{Recommended Citation}

Bernard H. Oxman, Complementary Agreements and Compulsory Jurisdiction, 95 Am. Jl. Int'l. Law 277 (2001).

This Article is brought to you for free and open access by the Faculty and Deans at University of Miami School of Law Institutional Repository. It has been accepted for inclusion in Articles by an authorized administrator of University of Miami School of Law Institutional Repository. For more information, please contact library@law.miami.edu. 


\title{
COMPLEMENTARY AGREEMENTS AND COMPULSORYJURISDICTION
}

\author{
By Bernard H. Oxman
}

Since the founding of the United Nations, the number of treaties and the matters they address have expanded vastly. It is increasingly common to find the same subjects addressed in complementary global, regional, and bilateral treaties. Many of these treaties contain provisions on the settlement of disputes regarding the interpretation or application of that treaty itself. Only some of those provisions establish compulsory jurisdiction. These circumstances suggest an increasing probability that a dispute will arise between states under the substantive provisions of two complementary treaties with dispute settlement clauses, only one of which provides for compulsory arbitration or adjudication either in general or with respect to that dispute.

Efforts in the last century to gain global acceptance of compulsory jurisdiction over all legal disputes between states have not succeeded, at least not fully and not yet. Nevertheless, significant movement in this direction may be discerned in the dispute settlement provisions of global multilateral treaties establishing particular regimes. Many such treaties may be, and often are designed to be, complemented by agreements that are more limited in their substantive or geographic scope. What happens when we confront different dispute settlement clauses applicable to a dispute that arises under more than one treaty?

The technical problem may be difficult enough if both treaties provide for compulsory jurisdiction, but in different fora or under different conditions. The problem is more profound if one of the treaties contains dispute settlement clauses that do not provide for compulsory jurisdiction at all. What is its effect on compulsory jurisdiction under another treaty that establishes a relevant substantive regime? What is its effect on a treaty that does not contain a relevant substantive regime but deals with compulsory dispute settlement in general? ${ }^{1}$

The basic question is not whether the law of treaties contains rules designed to resolve conflicts between treaties. The underlying question is whether any conflict between different dispute settlement provisions necessarily exists when each treaty expressly addresses disputes arising under only that treaty. If a conflict does exist, is there a presumption for or against compulsory jurisdiction? It is in this context that we must ask what we are really doing when we apply some of the more familiar rules of the law of treaties. Where a global multilateral treaty establishes a long-term regime that is subject to compulsory jurisdiction and also contemplates complementary functional or regional agreements, rules that find

\footnotetext{
- Of the Board of Editors. In preparing this article, I had the benefit of numerous helpful observations from valued colleagues who enriched my understanding; however, I have refrained from discussing the Southern Bluefin Tuna case with those who participated in the case, although some have seen an earlier draft study circulated at the Third Trilateral Conference in Ottawa on October 27,2000. In this connection I note that I responded at an early stage to certain specific queries from counsel representing Japan relating to the application for provisional measures in that case but did not participate in the drafting or presentation of the written or oral pleadings before either tribunal. My comments on the Third UN Conference on the Law of the Sea are based in part on my observations as U.S. representative and vice chairman of the U.S. delegation to the conference and chairman of the English Language Group of the Drafting Committee.

${ }^{1}$ Declarations under the optional clause of the Statute of the International Court of Justice (ICJ), Article 36(2), presumably would fall in this category.
} 
a conflict and then accord priority to the agreement that is later in time or more specific might well be rules that, consciously or otherwise, contain a built-in presumption against giving effect to compulsory jurisdiction clauses in the global treaty.

Where, as is often the case, the relevant treaties do not expressly address the issue, what do we infer? In drafting dispute settlement clauses, must governments expressly indicate their intent to preserve or their intent to derogate from otherwise applicable compulsory jurisdiction agreements in order to achieve that result? The "expressly preserve" position is rooted in what one might call a Westphalian conception that is loath to find restraints on state autonomy and quick to find an intent to retain or restore that autonomy. The "expressly derogate" position is rooted in what one might call a regime-building conception that defers to state autonomy in derogation of an agreed regime only when expressly retained. ${ }^{2}$ The latter approach is used for technical regulation undervarious treaties when strict uniformity in principle is either unnecessary or unattainable: expedited procedures for technical amendment or the adoption of regulations are subject to a right to expressly "opt out" of a specific amendment or regulation. It is also the approach used for reservations to multilateral treaties.

The response to the issues posed by this puzzle may well be the handy hedge, "That depends." One of the things it may depend on is the nature of the substantive regime. In this regard it makes sense to take a closer look at the UN Convention on the Law of the Sea for several reasons. Among them is the fact that an arbitral tribunal, presided over by Judge Stephen Schwebel, recently declined jurisdiction under the Convention because the dispute also arose under a complementary regional treaty whose dispute settlement clauses do not provide for compulsory jurisdiction. How judges and lawyers react to this award may well determine the answer to many basic questions regarding the effect of compromissory clauses, not only in the Law of the Sea Convention but in many other instruments. Ultimately, it may affect the efficacy of any effort to rest compulsoryjurisdiction on a global base in a largely decentralized international legal system.

\section{WHICH CONSTITUTION FOR THE OCEANS?}

The United Nations Convention on the Law of the Sea (LOS Convention) ${ }^{3}$ effects a comprehensive allocation of powers and responsibilities for the governance of all uses of over two-thirds of the planet. Its substantive range is broader than that of any other lawmaking treaty. It contains provisions regarding defense and international security, trade and communications, management of living and nonliving resources, scientific research, preservation of cultural heritage, and human rights; it has been described as "the strongest comprehensive environmental treaty now in existence or likely to emerge for quite some time." Reservations are not permitted. ${ }^{5}$ Its parties comprise a large majority of states. ${ }^{6}$ For a significant number of these states, the Convention may establish one of the broadest commitments to compulsory arbitration or adjudication yet made.

\footnotetext{
${ }^{2}$ The term "regime" is used here in the limited sense of a legally binding system largely established by treaty.

${ }^{3}$ United Nations Convention on the Law of the Sea, opened for signature Dec. 10, 1982, 1833 UNTS 397 [hereinafter LOS Convention].

${ }^{4}$ Letter of Submittal from the Secretary of State to the President (Sept. 23, 1994), forwarded with MESSAGE FROM THE PRESIDENT OF THE UNTED STATES TRANSMITTING THE UNITED NATIONS CONVENTIONONTHE LAW OF THE SEA, S. TREATY DOC. NO. 103-39, at v, vi-vii (1994) [hereinafter MESSAGE FROM THE PRESIDENT]. The Department of State distributed copies of these documents, including the extensive executive branch commentary that accompanied them, to foreign governments in capitals and at multilateral meetings, and posted them on its Web site at <http://www.state.gov/www/global/oes/oceans/index.html> (visited Jan. 29, 2001).

${ }^{5}$ LOS Convention, supra note 3 , Art. 309.

${ }^{6}$ There were 135 parties to the Convention as of April 23, 2001. Status of the United Nations Convention on the Law of the Sea and Related Agreements as at 23 April 2001, at<http://www.un.org/Depts/los/status2001.pdf $>$ (visited Apr. 23, 2001).
} 
The LOS Convention has been called a constitution for the oceans. ${ }^{7}$ What this means can be understood in widely different ways. What is the role of the LOS Convention in the system of ocean governance and its relation to the many other treaties that deal with the sea? Is it in the foreground or the background? What is the role of compulsory jurisdiction under the LOS Convention in that system? Is it in the foreground or the background? Different answers to those questions may influence the resolution of many issues involving the relationship between the LOS Convention's compulsory jurisdiction provisions and the many complementary agreements and institutions to which the Convention refers.

According to what might be called a substantive model, influenced in some measure by a regime-building conception, the LOS Convention stands at the heart of the public order of the oceans, and compulsory jurisdiction is integral to that public order. ${ }^{8}$ The primary function of the Convention is to lay down basic substantive principles and rules regarding the rights and duties of states concerning the sea. From this perspective, compulsory jurisdiction under the LOS Convention is designed to ensure both authoritative articulation of the meaning of the public order established by the Convention and compliance with its substantive principles and rules. The Convention's requirements that states establish and cooperate in a variety of complementary agreements and institutions entail both rights and responsibilities. Compulsory jurisdiction exists to ensure that failure to reach agreement in those contexts does not result in activities at sea that violate the Convention itself, including its environmental and conservation norms.

According to what might be called a procedural model, ${ }^{9}$ influenced in some measure by a Westphalian conception, the LOS Convention is to be implemented by political arrangements that translate its general principles into precise legal measures, and compulsory jurisdiction is ancillary to the system of political institutions established to implement those principles. By way of analogy, statutes, not constitutions, are the stuff of everyday municipal law. Municipal courts may treat their respective constitutions as "background" or "residual" law distributing power to political organs with only episodic interference at the margins from a court entrusted with the ultimate authority to interpret and apply the constitutional order. ${ }^{10}$ The same tendency may be observed in courts empowered to review the consistency of actions of administrative agencies with the statutes governing those agencies. ${ }^{11}$ Regulations, not constitutive statutes, are the stuff of everyday law here. If the LOS Convention requires states to establish and cooperate in a variety of complementary agreements and institutions, deference is due the right of a state to refuse to agree on specific substantive or dispute settlement measures in the context of those agreements and organizations. From this perspective, deadlock in political organs may well be regarded as an ordinary characteristic of the political process that does not, in itself, necessarily justify judicial intervention.

\footnotetext{
7 "A Constitution for the Oceans" is the title of remarks by Tommy T. B. Koh, president of the Third United Nations Conference on the Law of the Sea, that introduce the LOS Convention in the first edition published by the United Nations. He writes, "The question is whether we achieved our fundamental objective of producing a comprehensive constitution for the oceans which will stand the test of time. My answer is in the affirmative ...." Among the eight reasons given for the affirmative response is the following: "The world community's interest in the peaceful settlement of disputes and the prevention of use of force in the settlement of disputes between States have been advanced by the mandatory system of dispute settlement in the Convention." UNITED NATIONS, OFFICIAL TEXT OF THE UNITED NATIONS CONVENTION ON THE LAW OF THE SEA WTTH ANNEXES AND INDEX, UN Sales No. E.83.V.5, at xxxiii (1983).

${ }^{8}$ See Koh, supra note 7.

${ }^{9}$ As chance would have it, while working on these points I had the privilege of attending a faculty seminar at the University of Miami School of Law at which Frank Michelman, reflecting on the insights of Habermas, Rawls, and others, discussed the substantive and procedural functions of municipal constitutions and certain of their implications. While perhaps broadly informed by analogous considerations in constitutional theory, the purposes for which such a distinction is introduced here are decidedly narrower and more tentative.

${ }^{11}$ I would like to thank Patrick Gudridge for this observation.

${ }^{11}$ See Chevron USA v. Natural Res. Def. Council, 467 U.S. 837 (1984).
} 
Both models may be right. Either in isolation may be wrong. It is a question of emphasis. The appropriate emphasis may depend on how the LOS Convention deals with a particular subject.

\section{Dispute Settlement Provisions of the LOS Convention}

Part XV of the LOS Convention addresses the settlement of disputes. Section 2 of Part XV establishes compulsory procedures entailing binding decisions; it begins with Article 286: "Subject to section 3, any dispute concerning the interpretation or application of this Convention shall, where no settlement has been reached by recourse to section 1 , be submitted at the request of any party to the dispute to the court or tribunal having jurisdiction under this section." 12

Article 282 of the LOS Convention entails no exception to the principle of compulsory and binding third-party settlement set forth in Article 286. It deals with choice of forum: the means of compulsory and binding third-party settlement set forth in the Convention do not supplant a forum for such settlement otherwise chosen by both parties. ${ }^{13}$ Other dispute settlement provisions of the Convention reflect the same view: the end result, compulsory and binding third-party settlement, is the essence; the forum is secondary. ${ }^{14}$

${ }^{12}$ Articles 281 and 282, discussed immediately hereafter, are both in section 1 . Section 3 contains limitations and exceptions to compulsory jurisdiction.

${ }^{13}$ Article 282 of the LOS Convention, supra note 3, provides:

If the States Parties which are parties to a dispute concerning the interpretation or application of this Convention have agreed, through a general, regional or bilateral agreement or otherwise, that such dispute shall, at the request of any party to the dispute, be submitted to a procedure that entails a binding decision, that procedure shall apply in lieu of the procedures provided for in this Part, unless the parties to the dispute otherwise agree.

${ }_{14}$ Article 287 offers the parties a choice of forum for disputes subject to compulsory and binding settlement under the LOS Convention: the International Tribunal for the Law of the Sea (ITLOS), the International Court of Justice, arbitration, or a special arbitration procedure for certain types of disputes. Arbitration is generally the forum if no choice is made or the parties make different choices. The LOS Convention thus rejects the view of those, largely outside governments, who might have sacrificed the principle of compulsory and binding third-party settlement under the Convention if it could be obtained only in conjunction with the simultaneous creation of a new standing tribunal that might compete or disagree with the ICJ. Since the Convention entered into force, a few who held that view have gone out of their way to argue that the scope of compulsory jurisdiction under the Convention is very limited, notwithstanding the fact that a narrow construction would affect not only the ITLOS, but the jurisdiction of arbitral tribunals and even the ICJ itself under the Convention. For a comprehensive review of the question, see Jonathan I. Charney, Is International Law Threatened by Multiple International Tribunals? 271 RECUEIL DES COURS 101 (1998).

The debate has continued. Judge Gilbert Guillaume, president of the International Court of Justice, decried the effects of the proliferation of standing tribunals before the UN General Assembly and its Sixth Committee (Oct. 26 \& 27, 2001, respectively), at<http://www.icj-cij.org/icjwww/ipresscom/iprstats.htm>. These statements do not elaborate on the implications of Article 95 of the UN Charter or treaties that rely on arbitration. Thus, while the Southerm Bluefin Tuna case is mentioned, see infra note 25, there is no reference to the possible tension between the reasoning of the arbitral award, infra note 15, and the reasoning of the Permanent Court of International Justice in upholding jurisdiction in Electricity Co. of Sofia and Bulgaria, Judgment, 1939 PCIJ (ser. A/B) No. 77. See infra note 97.

Not all ICJ judges support Judge Guillaume's view.Judge Higgins believes that the emergence of “new, highly specialised bodies, whose members are experts in a subject matter which becomes ever more complex, which are more open to non-State actors, and which can respond rapidly" is "an inevitable consequence of the busy and complex world in which we live and is not a cause of regret." Rosalyn Higgins, Respecting Sovereign States and Running a Tight Courtroom, 50 INT'L \& COMP. L.Q. 121, 122 (2001).

Questions of jurisdiction of other fora under the LOS Convention are inextricably linked to questions regarding the role of the IrIOS, not only with respect to its jurisdiction over the merits in similar cases but in other ways as well. Not many states have filed declarations choosing the ITLOS as the relevant forum under the LOS Convention. Apart from the jurisdiction of its Seabed Disputes Chamber (regarding deep seabed mining under Arts. 186-91 and Annex VI, Arts. 14, 35-40), the compulsory jurisdiction of the ITLOS over all parties to the LOS Convention extends only to cases under Article 292 concerning prompt release of vessels and crew (without regard to jurisdiction over the merits of any underlying dispute) and to provisional measures under Article 290(5) pending the constitution of an arbitral tribunal that prima facie would have jurisdiction. Limiting the jurisdiction of arbitral tribunals under the LOS Convention presumably would make it more difficult for the ITLOS to prescribe provisional measures, which requires a finding that prima facie an arbitral tribunal would have jurisdiction. See infra note 107. 
Unlike Article 282, Article 281 of the LOS Convention refers to agreements between the parties that may derogate from the principle of compulsory and binding third-party settlement set forth in Article 286. For that reason, its deference to such agreements is limited.

Article 281 provides:

1. If the States Parties which are parties to a dispute concerning the interpretation or application of this Convention have agreed to seek settlement of the dispute by a peaceful means of their own choice, the procedures provided for in this Part apply only where no settlement has been reached by recourse to such means and the agreement between the parties does not exclude any further procedure.

2. If the parties have also agreed on a time-limit, paragraph 1 applies only upon the expiration of that time-limit.

\section{The Southern Bluefin Tuna Case}

The arbitral award. In the first arbitration under the LOS Convention, the arbitral tribunal decided that it lacked jurisdiction to adjudicate the claims of Australia and New Zealand that Japanese high seas fishing for southern bluefin tuna (SBT) was being conducted in violation of Japan's conservation and management obligations under the Convention. ${ }^{15}$ The exceptions to jurisdiction in section 3 of Part XV as such were inapposite and in any event were not invoked. ${ }^{16}$ The dispute had not been settled by negotiation or other means under section $1 .{ }^{17}$ The relevant forum under section 2 was an arbitral tribunal constituted in accordance with Annex VII. In the broadest sense, the question before the arbitral tribunal was whether Article 286 means what it appears to say. The answer was no. ${ }^{18}$

The pivotal issue identified by the arbitral tribunal was the effect of an agreement concluded by the three parties to the arbitration, the 1993 Convention for the Conservation of Southern Bluefin Tuna (CSBT Convention). ${ }^{19}$ Its dispute settlement clauses provide for binding third-party settlement only with the consent in each case of all parties to the dispute. ${ }^{20}$ The tribunal's conclusions might be summarized as follows:

(1) the dispute between the parties concerning the interpretation and application of the LOS Convention with which the tribunal was seized, and their dispute concerning the interpretation or implementation of the CSBT Convention, are the same dispute;

(2) the provisions of the CSBT Convention regarding settlement of disputes, notwithstanding the fact that they expressly refer only to a dispute "concerning the interpretation

${ }^{{ }^{5}}$ Southern Bluefin Tuna Case (Austl. \& N.Z. v. Japan), Jurisdiction and Admissibility, 39 ILM 1359 (2000), at <http://www.oceanlaw.net/cases/tuna2a.htm > [hereinafter Award]. See case notes by Barbara Kwiatkowska, Case Report: Southern Bluefin Tuna (Australia and New Zealand v.Japan), 95 AJIL 162 (2001), and by Philippe Weckel \& Eddin Helali, 104 REVUE GÉNÉRALE DE DROIT INTERNATIONAL PUBLIC 1037 (2000).

${ }^{16}$ The arbitral tribunal, however, did consider them relevant to the resolution of other jurisdictional issues. See Award, supra note 15, paras. 60-62; see also infra note 74 and corresponding text.

${ }^{17}$ See Award, supra note 15, para. 55.

${ }^{18}$ See id., para. 53.

${ }^{19}$ Convention for the Conservation of Southern Bluefin Tuna, May 10, 1993, 1819 UNTS 360.

${ }^{20}$ Id., Article 16 provides:

1. If any dispute arises between two or more of the Parties concerning the interpretation or implementation of this Convention, those Parties shall consult among themselves with a view to having the dispute resolved by negotiation, inquiry, mediation, conciliation, arbitration, judicial settlement or other peaceful means of their own choice.

2. Any dispute of this character not so resolved shall, with the consent in each case of all parties to the dispute, be referred for settlement to the International Court of Justice or to arbitration; but failure to reach agreement on reference to the International Court of Justice or to arbitration shall not absolve parties to the dispute from the responsibility of continuing to seek to resolve it by any of the various peaceful means referred to in paragraph 1 above.

3. In cases where the dispute is referred to arbitration, the arbitral tribunal shall be constituted as provided in the Annex to this Convention. The Annex forms an integral part of this Convention. 
or implementation of this Convention," constitute an agreement for the settlement of the same dispute concerning the interpretation or application of the LOS Convention; and

(3) the effect of the provisions of the CSBT Convention regarding settlement of disputes, notwithstanding the absence of an express reference to dispute settlement obligations under other treaties in general or the LOS Convention in particular, is to exclude compulsory jurisdiction under both Conventions.

The reasoning of the arbitral award reflects the procedural model of the role of the LOS Convention and its compulsoryjurisdiction provisions. It defers to the specific arrangements established by the parties in the CSBT Convention. It relies on the characterization of the LOS Convention as a "framework" or "umbrella" convention. ${ }^{21}$ It does not treat compulsory jurisdiction as integral to the regimes established by the LOS Convention in general or for high seas fisheries in particular. Relying on the exceptions to compulsory jurisdiction set forth in section 3 of Part XV of the LOS Convention, and the continuing right of the parties to agree on the means for settling disputes between them in section 1, the award stresses that the compulsoryjurisdiction regime established by section 2 of the Convention is not comprehensive..$^{22}$ It accords little, if any, weight to the fact that, unlike some other treaties, the LOS Convention does not affirmatively list specific disputes that are subject to compulsory jurisdiction, but establishes compulsory jurisdiction as the norm and then lists exceptions.

The provisional measures order. The $4-1^{23}$ decision of the arbitral tribunal came a year after a provisional measures order in the same case. In that order the International Tribunal for the Law of the Sea (ITLOS) found that prima facie the arbitral tribunal to be constituted would have jurisdiction over the dispute, a finding from which none of the twenty-two judges dissented. ${ }^{24}$

The conclusion that prima facie the arbitral tribunal would have jurisdiction is not necessarily inconsistent with a subsequent conclusion that it does not have jurisdiction. ${ }^{25}$

${ }^{21}$ Award, supra note 15, para. 29.

${ }^{22} I d$., para. 62.

${ }^{23}$ Voting in favor were Stephen Schwebel (president), Florentino Feliciano, Per Tresselt, and Chusei Yamada. Sir Kenneth Keith dissented.

${ }^{24}$ Southern Bluefin Tuna (NZ v. Japan; Austl. v. Japan), Provisional Measures (Aug. 27, 1999), 38 ILM 1624 (1999). IrLOS decisions and other documentation on the Tribunal are available online at $<\mathrm{http}: / /$ www.un.org/ Depts/los/index.htm>. Australia and New Zealand appointed Ivan Shearer as judge ad hoc to sit with the twentyone elected judges, including Judge Soji Yamamoto of Japan. This was the first case in which the ITLOS was called upon to prescribe provisional measures pending the constitution of an arbitral tribunal under Article 290(5) of the LOS Convention. See Barbara Kwiatkowska, Case Report: Southern Bluefin Tuna (New Zealand v. Japan; Australia v. Japan), 94 AJL 150 (2000).

${ }^{25}$ For the prescription of provisional measures, Article 290 of the LOS Convention requires that there be a finding by the tribunal that prima facie it "has" jurisdiction to adjudicate the merits or, under paragraph 5 , that an arbitral tribunal "would have" such jurisdiction. The ITLOS applied here, and in its earlier provisional measures decision in the Saiga case, M/V "Saiga," Provisional Measures (Mar. 11, 1998), 37 ILM 1202 (1998), the standard for jurisdiction with respect to provisional measures firstarticulated by the ICJ in the first Fisheries Jurisdiction cases; namely, that there is a basis upon which jurisdiction on the merits might be founded. Fisheries Jurisdiction (UK v. Ice.; FRG v. Ice.), Interim Protection, 1972 ICJ REP. 12, 15-16 (Aug. 17). "Whether 'might' means 'possibly might' or 'might well' or 'might probably' is a question of some controversy." Military and Paramilitary Activities in and Against Nicaragua (Nicar. v. U.S.), Provisional Measures, 1984 ICJ REP. 169, 207 (May 10) (diss. op. Schwebel, J.) [hereinafter Nicaragua].

In ICJ cases, the Court inquires whether an instrument exists apart from its Statute and the UN Charter upon which its jurisdiction might be founded. Because Article 286 of the LOS Convention establishes compulsory jurisdiction over any dispute concerning the interpretation or application of the Convention not otherwise excluded, depending on how one understands the "might" standard, there may always be a basis upon which jurisdiction "might" be founded under the Convention unless, pursuant to the companion standard indicated in the Fisheries Jurisdiction cases, "the absence of jurisdiction on the merits is manifest" by virtue of the exclusions in the Convention. Thus, by applying the standards articulated in Fisheries Jurisdiction to provisional measures cases under the LOS Convention, a tribunal could well be limiting itself to only the latter test. One may question whether that alone constitutes an appropriate application of Article 290. On its face, Article 290 appears to require an affirmative finding that prima facie there is jurisdiction, not merely a finding that the absence of jurisdiction is not manifest. 
The urgency inherent in requests for provisional relief pendente lite ${ }^{26}$ often affords neither the parties nor the judges the time for thorough research and analysis of jurisdictional questions at the provisional measures stage. ${ }^{27}$ The time available to the parties and the judges in the two proceedings in the instant matter differed substantially. ${ }^{28}$ The precise jurisdictional argument that prevailed in the arbitral tribunal was neither fully developed before the ITLOS nor specifically analyzed in its order. One of the central functions of provisional measures is to allow time for an orderly deliberative process without fear of irreparable injury in the interim, an important consideration when the underlying claim relates to ongoing fishing for a species whose conservation may be at risk. ${ }^{29}$ The fact that binding provisional measures were ordered and in effect in the $S B T$ case may in itself have made it easier for the arbitrators to provide for consideration of the jurisdictional issues in depth and at length.

That said, rarely has the same international tribunal ordered provisional measures only to decide subsequently that it lacked jurisdiction over the merits. ${ }^{30}$ One may suppose that differences not only in time and in the standard for jurisdictional determinations for purposes of provisional measures, ${ }^{31}$ but also in the appreciation of the standard for jurisdiction over the merits and in the composition of the two tribunals ${ }^{32}$ may have played a role in the

Since the jurisdictional standard at the provisional measures stage is not the same as the standard on the merits, and since the LOS Tribunal has consistently applied the ICJ's articulation of the jurisdictional standard for provisional measures, it is curious that Judge Guillaume chose to cite the difference in result reached by the two $S B T$ tribunals on jurisdiction as an illustration of his concerns regarding proliferation of tribunals. See Guillaume, supra note 14. Moreover, he makes no reference to the elaborate reliance on ICJ precedent in ITLOS opinions. There were some fifty citations to ICJ and PCIJ opinions in the first five decisions of the ITLOS.

${ }_{2 i \mathrm{i}}$ [II] $\mathrm{t}$ is of the essence of a request for interim measures of protection that it asks for a decision by the Court as a matter of urgency." Pakistani Prisoners of War (Pak.v. India), Interim Protection, 1973 ICJ REP. 328, 330 (July 13). Article 290 (5) of the LOS Convention expressly requires a finding that the urgency of the situation requires the Tribunal to prescribe provisional measures pending the constitution of an arbitral tribunal.

${ }_{27}$ The need for urgency is reflected in the Statute of the ITLOS, which permits provisional measures to be prescribed by a chamber of summary procedure formed under Article 15(3) "[w] ith a view to the speedy dispatch of business" if a quorum is unavailable. LOS Convention, supra note 3, Annex VI, Arts. 15(3), 25. It is also reflected in Article 90 of the Rules of the Tribunal, which, but for prompt-release proceedings, affords a request for provisional measures priority over all other proceedings before the Tribunal.

${ }^{28}$ See Award, supra note 15, para. 37. Australia and New Zealand notified Japan on July 15, 1999, of their intent to institute arbitral proceedings under the LOS Convention and to seek provisional measures from the ITLOS pending constitution of the arbitral tribunal. They filed the requests for provisional measures on July 30 . Hearings were held from August 18 to 20 on all issues relevant to the question of provisional measures. The ITLOS rendered its decision on August 27, 1999.

The parties then had many months to prepare for the jurisdictional hearings before the arbitral tribunal.Japan filed its objections to jurisdiction and admissibility on February 11,2000, and then had over a month to digest the reply of March 30 before the oral hearings devoted only to jurisdiction and admissibility, which lasted from May 7 through May 11. The award was rendered on August 4, 2000.

${ }^{2 y}$ Article 290(1) of the LOS Convention states that the purpose of provisional measures is "to preserve the respective rights of the parties to the dispute or to prevent serious harm to the marine environment, pending the final decision." Although it doubtless could be read into the classic purpose of preserving the rights of the parties, the express reference to environmental protection notably follows "or." In the context of this Convention, it should be understood to include protection of the environmental interests of all states in preventing serious harm to the marine environment, not just the interests of the parties to the case.

${ }^{30}$ A well-known example is Anglo-Iranian Oil Co. (UK v. Iran), Jurisdiction, 1952 ICJ REP. 93 (July 22).

${ }^{31}$ Paragraph 37 of the award refers to the difference in time available in the two proceedings and the different standard applicable to jurisdictional questions at the provisional measures stage.

${ }_{92}$ The arbitral tribunal was presided over by a judge who, among other things, had devoted considerable attention to arbitration as both a scholar and an arbitrator and who had addressed numerous jurisdictional questions in that context and during a long and distinguished tenure on the ICJ culminating in his service as its president. Moreover, while many of the judges of the ITLOS had been active and prominent participants in the negotiation of the LOS Convention over many years, of the arbitrators only Per Tresselt had played such a role. Whether judges are at their best when dealing with issues to which they have devoted great attention in the past is a question not easily resolved. I first encountered the question as a lawstudent when Professor Herbert Wechsler told our class that he and Professor Henry M. Hart, Jr., had informed Justice Frankfurter, then serving on the U.S. Supreme Court, that they proposed to dedicate their casebook, The Federal Courts and the Federal System (1953), "to Felix Frankfurter who first opened our minds to these problems," a reference to the Justice's prior scholarship and teachings. On the copy returned to the authors, at the end of the dedication Justice Frankfurter had penned in the words "and closed his own." 
instant matter. In this regard, it appears that the provisional measures order largely reflects the substantive model of the role of the Convention and its compulsory jurisdiction provisions.

\section{General Presumptions and Particular Treaties}

The president of the arbitral tribunal once observed in another case, "The nub of the matter appears to be that, while in deciding whether it has jurisdiction on the merits, the Court gives the defendant the benefit of the doubt, in deciding whether it has jurisdiction to indicate provisional measures, the Court gives the applicant the benefit of the doubt. ${ }^{\text {"13 }}$ It is not clear that others would agree that there is (or that the jurisprudence of the International Court of Justice (ICJ) confirms) an interpretive presumption in favor of the respondent with respect to jurisdiction over the merits; ${ }^{34}$ or, if so, that the presumption applies to jurisdiction predicated on the LOS Convention in light of the plain language of Article 286 establishing jurisdiction unless excluded by section 3, or that the presumption extends to the interpretation of a different instrument for purposes of deciding its effect on jurisdiction under the LOS Convention.

In this regard, a tribunal might conclude that, even if one continues to apply the broadest view of Lotus that restrictions on the freedom of action of states are not to be presumed, ${ }^{35}$ this freedom includes the freedom to contract. The modern law of treaties does not establish a presumption a priori in favor of either narrow or broad constructions of treaties. This presumably includes their dispute settlement provisions.

Dominating the background of such a debate is the traditional position that states are not subject to the jurisdiction of an international tribunal absent express consent ${ }^{36}$ But that does not explain the influence of the traditional position where jurisdiction is invoked under an instrument that, on its face, contains express consent to jurisdiction. Is the rule of consent itself merely a manifestation of a broader principle, rooted in Lotus perhaps, not only that acceptance of compulsory jurisdiction is not to be presumed but that retention of the right to agree to jurisdiction in each case is to be presumed? In other words, is agreement to compulsory jurisdiction to be narrowly construed, and are derogations from compulsory jurisdiction to be broadly construed?

An affirmative response to these questions may have substantial appeal, especially to those who represent states that have been sued, whether or not it accurately reflects the accumulated jurisprudence on the jurisdiction of international tribunals. But lying behind that response are two assumptions that are rarely articulated: first, that the risk of being sued without express consent specific to the case is worse than the risk of being unable to sue without the express consent of the defendant specific to the case, and second, that compulsory jurisdiction is ancillary to the functioning of international regimes.

Much has been and may be said in support of those assumptions, as reflecting both an accurate description of the attitudes of governments and a normative view that compulsory

\footnotetext{
${ }^{33}$ Nicaragua, Provisional Measures, supra note 25, 1984 ICJ REP. at 207 (diss. op. Schwebel, J.).

${ }^{34}$ Quite apart from the contention that no presumption in favor of the respondent is evident in the subsequent jurisdictional decision of the Court in the Nicaragua case itself, it might be argued that no such presumption is apparent from the reasoning of the Court in other cases. See Nicaragua, supra note 25, Jurisdiction and Admissibility, 1984 ICJ REP. 392 (Nov. 26); see also Oil Platforms (Iran v. U.S.), Preliminary Objections, 1996 ICJ REP. 803 (Dec. 12); Fisheries Jurisdiction (Spain v. Can.), Jurisdiction (ICJ Dec. 4, 1998); Aerial Incident of 10 August 1999 (Pak. v. India), Jurisdiction (ICJ June 21, 2000), 39 ILM 1116 (2000); Peter H. F. Bekker, Case Report: Aerial Incident of 10 August 1999 (Pakistan v. India), 94 AJIL 707 (2000). ICJ decisions are available online at <http:// www.icj-cij.org $>$. The absence of a presumption may even extend to whether there is a compromissory instrument at all. See Maritime Delimitation and Territorial Questions Between Qatar and Bahrain (Qatar v. Bahrain), Jurisdiction and Admissibility, 1995 ICJ REP. 6 ( Feb. 15).

${ }^{35}$ S.S. Lotus (Fr. v. Turk.), 1927 PCIJ (ser. A) No. 10, at 18-19.

${ }^{36}$ That view remains widely accepted notwithstanding the continuing erosion of the immunity of states from the jurisdiction of the municipal courts of other states, which in some ways is a more intrusive development because of the absence of influence of the defendant over the composition and procedures of the tribunal as well as the municipal law that the tribunal ordinarily applies.
} 
jurisdiction has limited utility in the international political process. Even so, one may ask whether those assumptions are invariably apposite. Especially where the compromissory agreement forms part of a constitutive instrument establishing a particular regime, should there be a more refined inquiry into the accuracy and pertinence of these (or any other) assumptions in that context? This question is particularly relevant to a fair number of regimes, including at least three widely accepted global regimes; namely, those established by the Convention on International Civil Aviation at the threshold of the post-World War II era, the new trade regimes established by the World Trade Organization (WTO) agreements, and of course the regime established by the LOS Convention.

The Inter-American Court of Human Rights, in a decision perhaps unthinkable in the context of the optional clause of the ICJ Statute, deduced from the object and purpose of the American Convention on Human Rights that, although acceptance of compulsory jurisdiction is optional, once a party to the American Convention has accepted such jurisdiction, it may not withdraw that consent without denouncing the Convention itself. ${ }^{37}$ Whether or not one agrees with the answer, the methodology has much to recommend it. The willingness to question whether traditional assumptions regarding compulsory jurisdiction apply in the context of the regime in question is rooted in a fundamental rule of treaty interpretation-arguably a fundamental rule of interpretation of all instruments-that terms are to be understood in context in light of the object and purpose of the instrument, and that the context notably includes the instrument as a whole. ${ }^{38}$

\section{Compulsory Jurisdiction and the LOS Convention}

The history of the LOS Convention readily reveals that many states regarded compulsory jurisdiction as integral to the very idea of a new convention on the law of the sea. The maritime powers that some might guess would wish to preserve the freedom to consent to jurisdiction in each case were in fact among the strongest supporters of compulsory jurisdiction. The United States, and perhaps more to the point, Australia, Japan, and New Zealand, ${ }^{39}$ indicated at an early stage their view of compulsory jurisdiction as an important

${ }^{37}$ Bronstein \& Constitutional Tribunal, Inter-Am. Ct. H.R. (ser. C), Nos. 54 \& 55 (Sept. 24, 1999), at <http://corteidh-oea.nu.or.cr/ci/Jurisprudencia/Juris.htm>; see Karen C. Sokol, Case Report: Ivcher Bronstein \& Constitutional Tribunal, 95 AJIL 178 (2001).

${ }^{98}$ See Vienna Convention on the Law of Treaties, opened for signature May 23, 1969, Art. 31, 1155 UNTS 331.

${ }^{39}$ For the United States, see Statement of Ambassador Stevenson, 69 DEP'T.ST. BULL. 412,414 (1973); Statement of Ambassador Learson (Apr. 6, 1976), 5 THIRD UNTTED NATIONS CONFERENCE ON THE LAW OF THE SEA, OFFICIAL RECORDS 31, paras. 17, 18 [hereinafter OFF. REC.]. The basis for this position was summarized as follows:

The developing factual (as distinguished from legal) situation in the oceans is one in which every country increasingly believes that it has, in effect, the option of pronouncing and attempting to achieve relevant acquiescence in its interpretation of the law .... Given the current trends in the law of the sea, there is reason to believe the process might continue even if a treaty were widely ratified. In the broadest sense, the purpose of the law of the sea negotiations is to put an end to the direct relationship that such a system entails between the enjoyment of a right and the application of power. A system of compulsory, impartial, third-party adjudication is thus an essential element of the overall structure.

John R. Stevenson \& Bernard H. Oxman, The Preparations for the Law of the Sea Conference, 68 AJIL 1, 31 (1974). (At the time, the authors were, respectively, special representative of the president for the law of the sea conference, and assistant legal adviser for ocean affairs of the Department of State. Copies of this article were circulated to foreign governments by the United States.)

For Australia, see Statement of Ambassador Harry (Apr. 5, 1976), 5 OFF. REC., supra, at 9, para. 12 (“[M]any provisions of the convention would be acceptable only if their interpretation and application were subject to expeditious, impartial and binding decisions."). For Japan, see Statement of Ambassador Ogiso (July 15, 1974), $1 \mathrm{id}$. at 182 , para. 54 ("Japan attached great importance to the establishment of a satisfactory procedure for compulsory settlement of any disputes which might arise out of the interpretation or application of the new convention."); Statement of Mr. Fujisaki (Apr. 6, 1976), 5 id. at 27, para. 54 ("Agreement on a compulsory dispute settlement procedure must be an essential element in an over-all solution of major issues in the current negotiations. "). For New Zealand, see Statement of Mr. Beeby (Apr. 5, 1976), 5 id. at 11, para. 30 ("[I]t would be essential to include, as an integral part of the convention, machinery for the compulsory third party settlement of disputes arising out of the interpretation or application of the convention.... If the Conference did not provide 
and integral element of a new convention and rejected the optional-protocol approach to compulsory jurisdiction used in the earlier 1958 conventions on the law of the sea. ${ }^{40}$ Although the $S B T$ arbitral tribunal indicated its awareness of the historic opposition of the Soviet Union to compulsory jurisdiction, ${ }^{41}$ nowhere does the award suggest that the tribunal had endeavored to ascertain whether the dramatic reversal of the Soviet position in the negotiation of the LOS Convention ${ }^{42}$ was rooted in perceptions of the object and purpose of that Convention and the nature of the regimes it would establish. ${ }^{43}$ While the arbitral tribunal emphasized the exceptions, it can be argued that in historical context the significant development in the LOS Convention is not that there are important exceptions to the principle of compulsoryjurisdiction enunciated in Article 286, but that Article 286 exists at all.

The objectives of many delegations in negotiating a new convention on the law of the sea derived principally from dissatisfaction not only with the results of reliance on the decentralized processes of customary law applied to unilateral claims of right at sea, but especially with the costs and perverse incentives of those processes. Governments well understood that a convention limited to articulating norms and rules-like the 1958 conventions on the law of the sea-might sooner or later fall victim to the same processes. Stability in the law required authoritative uniform articulation of the basic rights and duties of states in a manner flexible enough to accommodate different and changing circumstances. States that wished to discourage unilateral claims sought a "third option" between acquiescence and confrontation. This approach, in turn, required international mechanisms, in addition to unilateral responses, both to deal with unilateral claims and to accommodate the inevitable and inexorable pressures for adaptation and evolution that would otherwise once again destabilize the regime.

There was strong opposition to the idea of a new comprehensive oceans organization or its rough equivalent, a relaxed amendment procedure, as a solution to this problem. Instead, the conference chose two mechanisms to achieve the desired goal. One mechanism was characterized by traditional reliance on specialized global and regional agreements and

for such a system, it... would have failed to establish a permanent and stable solution to the problems confronting it.").

${ }^{40}$ Evidence of other early support for compulsory jurisdiction can be found in the statements made in plenary during the first full debate on dispute settlement. See 5 OFF. REC., supra note 39, at 8-9 (El Salvador), 10 (Singapore), 10-11 (USSR, implicitly), 13-14 (France, arbitration), 12-13 (Federal Republic of Germany), 14-15 (United Kingdom), 15-16 (Switzerland), 16-17 (Sri Lanka), 18-19 (Argentina), 19-20 (Chile), 20-21 (German Democratic Republic, implicitly), 21-22 (Belgium, Luxembourg, the Netherlands), 22-23 (Colombia), 23-24 (Spain), 24-25 (Italy), 25-26 (Portugal, Cyprus), 26-27 (Thailand, implicitly), 27-28 (Austria), 28-29 (Republic of Korea), 29 (Bulgaria, implicitly), 30 (Sweden), 32 (Yugoslavia), 32-33 (Poland, implicitly), 35 (Nigeria), 38-39 (Tunisia, Trinidad and Tobago), 41 (Bangladesh), 42-43 (Philippines, implicity), 43-44 (Uruguay), 47-48 (Ireland, Iraq), 48-49 (Fiji), 49-51 (Canada), 51 (Greece, Senegal). A significant number of other delegations joined these in supporting compulsoryjurisdiction beyond the limits of coastal state jurisdiction. "The Convention is unique among the major law-making treaties in establishing, as an integral part of its provisions, a comprehensive system for the settlement of disputes.... That such a result was attained represented a reversal of the trend then prevailing in international negotiations." GUDMUNDUR EIRIKSSON, THE INTERNATIONAL TRIBUNAL. FOR THE LAW OF THE SEA 11 (2000).

${ }^{41}$ Award, supra note 15, para. 58.

42 Similar developments occurred in contemporaneous negotiations under the auspices of the International Maritime Organization. See International Convention Relating to Intervention on the High Seas in Cases of Oil Pollution Casualties, Nov. 29, 1969, Art. 8, 26 UST 765, 970 UNTS 211; International Convention for the Prevention of Pollution from Ships, Nov. 2, 1973, Art. 10, 12 IIM 1319 (1973), 1313 UNTS 3. Regular consultations between the Soviet Union and the United States regarding the objectives of a possible third UN Conference on the Law of the Sea, led by the heads of the respective foreign ministry legal offices and including senior representatives of various ministries, had already begun when these instruments were negotiated.

${ }^{43}$ Those familiar with the history of Soviet resistance to compulsory jurisdiction will appreciate the astonishment of many individuals present when a Soviet Foreign Ministry lawyer denounced, as a wholly inadequate formula that was more likely to perpetuate than settle disputes, a suggestion to deal with the matter in the LOS Convention by reaffirming Article 33 of the UN Charter. See BERNARD H. OXMAN, FROM COOPERATION TO CONFLICT: THE SOVIET UNION AND THE UNITED STATES AT THE THIRO U.N. CONFERENCE ON THE LAW OF THE SEA 13-14 (1985). 
organizations to implement certain provisions of the Convention. The other mechanism was reliance on compulsory dispute settlement to a degree unprecedented in a lawmaking convention of such broad scope.

The provisions regarding environmental protection afford a good example. The obligation of states to protect and preserve the marine environment is set forth in its own article in unqualified form at the start of Part XII. The Convention includes other general legal principles previously found mainly in declarations. Obligations to develop and enforce specific antipollution measures are outlined in great detail. States are to execute these obligations directly and through global and regional organizations and arrangements. However, the Convention closes gaps in ratification or implementation of global pollution control treaties that may emanate from that process by introducing a duty to enforce generally accepted international rules and standards promulgated by the competent international organization. It was well understood that environmental rights and duties would be subject to compulsory jurisdiction. Indeed, it is hard to imagine that agreement could have been reached on the complex problems of navigation and pollution from ships in any other way, because coastal states sought reassurance that flag states could be compelled to fulfill their duties, and maritime states sought reassurance that coastal states could be compelled to respect navigational rights and interests in the exercise of regulatory or enforcement powers. Compulsory jurisdiction is central both to realizing and to accommodating two of the most important goals of the Convention: protecting navigation and protecting the environment.

In brief, ample intrinsic and extrinsic evidence supports the conclusion that, whatever the ordinary relationship between treaties and compulsory jurisdiction, in the LOS Convention the latter constitutes an integral part of the regime created by the former. This conclusion suggests that the substantive model of the Convention's role cannot be ignored, at least with respect to issues that are not excluded from compulsory jurisdiction under section 3 of Part XV.

\section{The Relationship Between Political and Judicial Organs}

The interpretation and application of many constitutive instruments presents an underlying problem of sorting out the relationship between the political and judicial mechanisms employed to implement the public order thus established. The LOS Convention expressly addresses the relationship between political and judicial organs in two contexts. First, although the ICJ, the principal judicial organ of the United Nations, has determined that the primary responsibility of the UN Security Council for the maintenance of international peace and security under the UN Charter does not preclude the Court from hearing a case, ${ }^{44}$ the LOS Convention permits a state to declare in writing that it does not accept compulsory jurisdiction under the Convention with respect to

disputes in respect of which the Security Council of the United Nations is exercising the functions assigned to it by the Charter of the United Nations, unless the Security Council decides to remove the matter from its agenda or calls upon the parties to settle it by the means provided for in this Convention. ${ }^{45}$

Second, a specific article sets forth the scope of the review powers of the ITLOS Seabed Disputes Chamber over the International Seabed Authority, ${ }^{46}$ and another provision states

\footnotetext{
${ }^{4}$ United States Diplomatic and Consular Staff in Tehran (U.S. v. Iran), 1980 ICJ REP. 3, para. 40 (May 24); Nicaragua, Jurisdiction and Admissibility, supra note 25, paras. 93-98.

${ }^{45}$ LOS Convention, supra note 3, Art. 298(1) (c).

${ }^{45}$ Id., Art. 189. In cases excluded from compulsory arbitration or adjudication but subject to compulsory conciliation, there are analogous requirements that a conciliation commission defer to the discretionary rights of the coastal state regarding scientific research and fisheries management in areas subject to coastal state jurisdiction. See id., Art. 297, paras. 2(b), 3(c).
} 
that a "commercial arbitral tribunal to which [a deep-seabed-mining contract] dispute is submitted shall have no jurisdiction to decide any question of the interpretation of this Convention" and must refer that question to the Seabed Disputes Chamber. ${ }^{47}$

These provisions may reflect, at least in part, a belief-hardly original to this Convention-that the perspectives of tribunals that are institutional components of the relevant regulatory regime and are elected by all its members differ from those of tribunals that are not. Even if the ITLOS and an arbitral tribunal both derive their jurisdiction from the LOS Convention, do they see their relationship to the Convention and its other implementing institutions in the same way? ${ }^{48}$ Is part of the explanation for the marked difference in views on jurisdiction between the judges of the ITLOS and the majority of the arbitral tribunal to be found in the fact that the ITLOS judges regarded themselves as part of the system created by the Convention, while at least these arbitrators saw themselves as outsiders looking in ${ }^{49}$

Both of the express provisions of the LOS Convention on the relationship between judicial and political organs address specific global institutions with established competence and decision-making procedures. In other contexts, and notably that of high seas fisheries, the implementing arrangements and organizations are not necessarily global and their composition, competence, and decision-making procedures are unknown and may vary. Binding decisions in many such arrangements and organizations may require the express agreement of each party. In that case, the analogy to municipal regulatory agencies or other governmental organs is arguably weaker, if not inapposite. The arrangement or organization itself provides little more than a context for concluding strictly consensual agreements. Contract negotiation, not administrative decision making, is presumably the better analogy. To that extent, the case for reliance on political organs as part of the constitutional structure may be substantially attenuated. The issue becomes one of the freedom of action of the state that refuses to circumscribe its nationals' activities at sea either directly or through the arrangement or organization in question, and the remedies available to states that believe those activities violate underlying norms.

Here history is important. The ineffectiveness of high seas fisheries management organizations and agreements contributed in significant measure to the collapse of pivotal elements of the traditional regimes codified by the 1958 conventions on the law of the sea. It was a principal "evil sought to be remedied" by the LOS Convention through the introduction of two new jurisdictional elements: the regulatory and enforcement competence of the coastal state over fishing in the exclusive economic zone (EEZ), and the compulsory jurisdiction of international tribunals over high seas fishing beyond the EEZ. The first largely eliminates the power of the flag state to insist that conservation and management measures may not be applied to its fishing vessels without its consent; the second circumscribes it. ${ }^{50}$

${ }^{47}$ Id., Art. 188(2).

${ }^{48}$ To some extent the LOS Convention anticipates this issue. Article 2(1) of Annex VII provides for a list of arbitrators to be drawn up and maintained by the UN Secretary-General. Each state party is entitled to nominate four arbitrators "experienced in maritime affairs." Article $3(b)-(d)$ provides that arbitrators appointed by the parties shall be "preferably from the list." Failing the requisite appointments by the parties, those appointments "shall be made from the list" by the president of the ITLOS. Governments have been slow to make their nominations to the list. In the $S B T$ case, the parties to the dispute agreed on distinguished individuals who were not on the list.

${ }^{49}$ The LOS Convention is by no means the only regulatory treaty to employ arbitration as a principal means of compulsory dispute settlement between states. In other areas-trade readily comes to mind-one does not seem to encounter many complaints about a lack of a sense of participation in the regulatory and dispute settlement regime under which arbitrators are appointed. Some environmentalists argue that the problem with trade arbitration is the reverse.

${ }^{50}$ While the balance struck is substantially different, the LOS Convention employs the same two jurisdictional elements (plus a third, port state jurisdiction) to deal with what was a less widespread, but equally destabilizing, problem under the traditional regimes, namely, regulation of pollution from ships. Freedom of fishing was a 
Since the provisions of the LOS Convention regarding high seas fishing rely on regional and other agreements and organizations to establish specific conservation and management measures, ${ }^{51}$ it appears that a significant reason for including, indeed specifically including, ${ }^{52}$ compulsory jurisdiction over high seas fishing was to afford states a means to ensure compliance with the Convention's underlying conservation and management norms when the political process deadlocks.

The limitations on the flag state's freedom of action and the reliance on compulsory jurisdiction emerge even more clearly in the 1995 Agreement for the Implementation of the Provisions of the United Nations Convention on the Law of the Sea of 10 December 1982 Relating to the Conservation and Management of Straddling Fish Stocks and Highly Migratory Fish Stocks (Straddling Stocks Agreement). ${ }^{53}$ That Agreement facilitated the ratification of the LOS Convention by addressing the precise threat to the acceptance and stability of the regimes established by the LOS Convention that had destabilized the prior regimes; namely, unilateral coastal state claims beyond established limits in response to perceptions of the unwillingness or inability of flag states to meet their conservation and management obligations on the high seas either directly or through regional arrangements and organizations. ${ }^{54}$ In the broadest sense, when tribunals encounter deadlock under regional arrangements and organizations that threatens conservation of high seas fisheries, they confront not only the meaning of the public order established by the LOS Convention, but in some measure its very existence as a constitutive instrument.

From this perspective, it might be difficult to anticipate that a tribunal faced with such a deadlock would reject the substantive model and extend the procedural model to the point of regarding the parties' mutual promises to endeavor to adopt fisheries conservation measures and settle disputes by agreement as an execution of substantive conservation and management duties under the LOS Convention sufficient not merely to delay judicial intervention until the emergence of a compelling case, ${ }^{55}$ but to supplant compulsoryjurisdiction altogether. ${ }^{56}$ How does this approach differ from according the same treatment to failure to reach agreement pursuant to a general duty to attempt in good faith to resolve a dispute by negotiation before invoking compulsoryjurisdiction? Yet any such general duty would be regarded as a prerequisite to, not a substitute for, compulsory jurisdiction. What does the specific agreement to negotiate add?

\section{IMPLIED COVENANTS NOT TO SUE}

The CSBT Convention as a whole, including its provisions on the settlement of disputes, is essentially an agreement to negotiate. Its dispute settlement provisions represent one variant of a wide range of provisions designed to avoid emphasizing what the parties unques-

consequence of Grotius's conception of mare liberum; freedom of navigation was its raison d'être. Freedom of navigation is directly implicated by unilateral coastal state claims of control over pollution from ships, dramatized by the dispute over navigation through Arctic waters that engaged the highest levels of the Canadian and United States governments in connection with Canada's unilateral claim of jurisdiction over foreign ships for pollution control purposes.

5t LOS Convention, supra note 3, Arts. 63(2), 64-67, 116-19.

[2. Id., Art. $297(3)$ (a).

${ }_{53}$ Agreement for the Implementation of the Provisions of the United Nations Convention on the Law of the Sea of 10 December 1982 Relating to the Conservation and Management of Straddling Fish Stocks and Highly Migratory Fish Stocks, Aug. 4, 1995, 34 ILM 1542 (1995) [hereinafter Straddling Stocks Agreement]. See infra note 145.

${ }^{*}$ For relevant background, see David Balton, Strengthening the Law of the Sea: The New Agreement on Straddling Fish Stocks and Highly Migratory Fish Stocks, 27 OCEAN DEv. \& INT'L L. 125 (1996); ERANCISCO ORREGO VICUÑa, THE CHANGING INTERNATIONAI LAW OF HIGH SEAS FISHERIES (1999).

Es See infra notes $145-53$ and corresponding text.

${ }^{56}$ In private law, the point of according legal effect to the avant-contrat is presumably to permitjudicial intervention, not the reverse. See infra note 110 . 
tionably understand; namely, that the agreement adds little of legal substance to the general obligation of states to settle disputes peacefully by means of their own choice under Article 33 of the UN Charter. ${ }^{57}$ A large number of agreements contain such provisions. ${ }^{58}$ The function of most of these provisions is (or at least until now was ordinarily assumed to be) largely cosmetic and superficially "face saving" for those who favored the inclusion of compulsory jurisdiction provisions. ${ }^{59}$

Now we are told that there is more to be found in such provisions. Coiled among the fig leaves may be an implied covenant not to sue. ${ }^{60}$ Construing provisions of a treaty that expressly refer exclusively to disputes concerning the interpretation or application of that treaty to constitute a covenant not to sue makes sense only if those provisions are understood to refer to a right to sue under another treaty or instrument. How many dispute settlement provisions of how many agreements that do not provide for compulsory jurisdiction are to be understood to constitute covenants not to sue that derogate from the right to sue under another treaty or instrument?

The remainder of this study will focus on that central question; namely, the extent to which the reasoning in the $S B T$ award might be regarded as relevant to other agreements in other contexts, and the consequences for the Law of the Sea Convention and other treaties of doing so. In this connection, at least three sets of questions should be considered for the future:

(1) When does the same dispute arise under two treaties, in particular two different regulatory treaties establishing different sources of obligation? What is the standard for making this determination for purposes of deciding the relationship between different dispute settlement clauses in the two treaties? ${ }^{\text {bl }}$

(2) When the same dispute arises under two treaties with different dispute settlement provisions, each expressly applicable only to disputes arising under one treaty, are those treaties compatible, ${ }^{62}$ each creating an alternative option for the aggrieved party? Is there a presumption for or against interpretations that would render those dispute settlement provisions compatible?

(3) If the treaties are deemed incompatible, what is the effect? Is there a presumption for or against applying the treaty that establishes compulsory jurisdiction (or particular types of compulsory jurisdiction)?

In considering these questions, one must bear in mind what is not at issue. The issue is not whether a treaty that expressly applies to the settlement of disputes arising under other instruments must necessarily identify each of those instruments by name. ${ }^{63}$ The issue is not whether states may agree to derogate from their compulsory dispute settlement obligations to each other. The issue is deciding when states should be deemed to have done so, and in particular the effect that a treaty whose dispute settlement clauses expressly refer only to

${ }^{57}$ See supra note 43.

${ }^{58}$ As the arbitral tribunal noted, the dispute settlement provisions of the CSBT Convention are largely derived from those of the Antarctic Treaty, Dec. 1, 1959, Art. XI, 12 UST 794, 402 UNTS 71. Award, supra note 15, para. 58. The approach of the Antarctic Treaty was repeated in the Convention on the Conservation of Antarctic Living Marine Resources, May 20, 1980, Art. XXV, 33 UST 3476, 19 ILM 841 (1980).

${ }^{59}$ In some states, the agreement, especially if approved by the parliament, might be viewed as authorizing the government to submit a dispute arising thereunder to arbitration or adjudication without specific parliamentary approval, thus facilitating resort to such procedures in states where parliamentary approval is ordinarily sought for legal or political reasons. That result would depend not only on the precise text of the agreement but on the constitution, laws, and traditions of the state concerned, as well as the political context in which the issue arises.

${ }^{60}$ The term "covenant not to sue" is not used in the arvard. That, however, is largely its effect.

${ }^{61}$ It is not necessarily the case that what is viewed as the same dispute for res judicata purposes should be regarded as the same dispute for jurisdictional or similar purposes. Whether a party should have options as to where to sue is a different question from whether a party should have the option to try again.

${ }^{62}$ SeeVienna Convention on the Law of Treaties, supra note 38, Art. 30(3) (compatibility test for successive treaties relating to the same subject matter). Article 311 (2) of the LOS Convention also employs the compatibility test.

${ }^{63}$ Article 36(2) of the ICJ Statute refers to "Iegal disputes concerning ... the interpretation of a treaty." 
disputes arising under that treaty should have on the compulsory jurisdiction provisions of a second treaty that expressly refer only to disputes arising under the second treaty. ${ }^{64}$

\section{THE RATIO DECIDENDIOF THE AWARD}

The ratio decidendi of the $S B T$ award needs to be determined only to the extent that, in another case, it is treated as authoritative precedent. No other tribunal, be it the IGJ, the ITLOS, or another arbitral tribunal, is bound to do ${ }^{6 .}{ }^{65}$ It may expressly or implicitly disagree.

While the inclination to afford precedential effect to prior decisions may be weaker in the case of arbitral awards, in reality such awards may have persuasive influence in future cases. For a variety of reasons, including the learning and experience of the arbitrators, those charged with arguing and deciding a future case that raises similar issues are likely to attempt to discern the ratio decidendi of the $S B T$ award, if only to determine the proposition to be accepted or rejected. The key point-familiar to students of the common law and other systems that treat judicial precedent as a source of law-is that, be it binding or merely persuasive, we cannot really know the precedential effect of a decision until that matter is addressed in a future case, perhaps many future cases.

Yet well before a tribunal pronounces on the effect of the award on a future case, lawyers advising governments will need to consider the issue in connection with the negotiation of new agreements. Ordinarily, it is relatively easy, and even necessary on occasion, to include dispute settlement provisions in an agreement that stop short of providing for compulsory jurisdiction. Now the prudent lawyer will need to consider at least four issues:

(1) Is it advisable to add a savings clause to dispute settlement provisions that do not provide for compulsory jurisdiction stating that nothing therein is intended to exclude compulsory jurisdiction under another instrument? The other side may of course perceive such a proposal as a signal of intent to sue, and a more complicated negotiation could result. What of the negative pregnant with respect to agreements that do not contain such a clause?

(2) Is it risky to propose noncompulsory dispute settlement provisions with no savings clause? What will the legal effect be on compulsory jurisdiction clauses in other instruments? The other side may perceive an attempt to trick it into undoing compulsory jurisdiction under another instrument.

(3) Where the parties may be otherwise subject to compulsory jurisdiction, is it best to avoid noncompulsory dispute settlement provisions in agreements, especially when their function is largely cosmetic? Does silence on dispute settlement necessarily eliminate the doubt?

(4) Where the intent is to exclude compulsory jurisdiction under other instruments, is it best to say so expressly?

Needless to say, similar issues arise in connection with a host of existing agreements. Should governments consider making a general statement on the matter relevant to existing agreements? If so, which agreements?

Moreover, the additional problem arises of how to draft compulsory jurisdiction clauses in multilateral constitutive treaties. Many such treaties are complemented by more limited arrangements regarding particular subjects or between particular states. Should the rule

\footnotetext{
is Treaties that provide for express waiver of alternative remedies are presumably distinguishable. See North American Free Trade Agreement, Dec. 17, 1992, Can.-Mex.-U.S., Art. 1121, 32 LM 605 (1993); see also infra note 71.

${ }^{55}$ Article 296 of the LOS Convention applies to any adjudication and arbitration under the Convention the rule that the "decision shall have no binding force except between the parties and in respect of that particular dispute." The rule applies to a decision "rendered by a court or tribunal having jurisdiction under this section"; the reference to "jurisdiction" in this context presumably includes compétence de la compétence. The rule is derived from Article 59 of the ICJ Statute.
} 
that the parties may agree to derogate from compulsory jurisdiction be retained? Would silence on the matter have the same effect anyway? If the rule is retained or at least not expressly negated, how does one avoid the problem of conflicting dispute settlement provisions regarding the "same dispute" and derogation by implication? Should the text of the multilateral treaty provide that, to be effective, an agreement to derogate from its compulsory jurisdiction provisions must expressly refer to compulsory jurisdiction under that particular treaty or under a class of treaties that clearly includes that particular treaty? If so, has one implicitly acknowledged the possibility of a broad reading of the ratio decidendi and general applicability of the $S B T$ award where such a provision is not included?

\section{Strict Interpretations of the Award}

Sir Kenneth Keith concluded in his dissenting opinion that the CSBT Convention does not exclude resort to the compulsoryjurisdiction provisions of the LOS Convention because the CSBT Convention does not expressly so provide. That view, if applied in a subsequent case, would entail a decision not to accord precedential effect to the award.

There are other possibilities. The ratio decidendi of the award, to the extent it is accorded precedential effect by another tribunal, can be framed so that the precedent would or would not be relevant to the issues in a future case ${ }^{66}$ Among the grounds for distinguishing the award from other cases, the following may be noted:

(1) The effect of an agreement is to be determined with reference to that agreement. This award decides the effect of the CSBT Convention and the actions of the parties thereunder. In this connection, one might consider the following distinguishing characteristics (many of which were noted in the award):

(a) The dispute originally arose under the CSBT Convention, and related to Japanese experimental fishing in excess of specific catch levels previously established by the parties pursuant to that Convention. Until a relatively late date, the issue was addressed by the parties with reference only to that Convention.

(b) The CSBT Convention was concluded prior to the entry into force of the LOS Convention but in light of the LOS Convention's conservation principles. ${ }^{67}$

(c) All parties to the CSBT Convention were party to the case. ${ }^{68}$ Indonesia, South Korea, and other states or entities whose vessels fish for southern bluefin tuna were not party to the case.

(d) The arbitral tribunal viewed the CSBT Convention as establishing a comprehensive regime with respect to southern bluefin tuna for the purpose of implementing the parties' obligations under the conservation and management provisions of the LOS Convention at issue in this case. ${ }^{69}$

\footnotetext{
${ }^{66}$ International tribunals are not composed exclusively of judges whose training in and understanding of law are rooted in common-law techniques of distinguishing holding from dictum and discerning the possibility of narrow holdings anchored to the particular facts of a case. Moreover, the absence of a rule of stare decisis can make a court less cautious about reading precedent broadly.

${ }^{67}$ Award, supra note 15, para. 29.

${ }^{63}$ The precise legal basis of the award is the conclusion that the parties agreed to exclude compulsory jurisdiction in the CSBT Convention. In that case the effect of the award arguably could be avoided if the applicant, or perhaps one of the applicants, were not party to such an agreement. This circumstance, however, might pose new difficulties. Where high seas fisheries conservation is concerned, all the interested states-both the coastal states and those whose vessels are engaged in the relevant fishery-are supposed to enter into cooperative arrangements with each other. That duty is even stronger under Article 8 of the Straddling Stocks Agreement. Thus, one might not often find a state interested enough to complain in court about overfishing that was not interested enough to participate in cooperative conservation efforts. Moreover, if the nonparty applicant were a directly interested fishing state, it would have a duty to cooperate directly with the states that were party to the relevant agreement. Under Article 8 of the Straddling Stocks Agreement, the duty would be either to join the organization or arrangement or to apply the conservation and management measures adopted pursuant thereto. See infra note 130. If such a state were the applicant, a tribunal might be compelled to confront deeper structural questions, namely, the underlying relationship between political negotiations and compulsory jurisdiction in giving effect to the high seas conservation and management norms of the LOS Convention and the Straddling Stocks Agreement.

${ }^{69}$ Award, supra note 15, para. 29.
} 
(e) All of the issues in the case arising under the LOS Convention were deemed to arise under the CSBT Convention as well.

(f) Depending on one's view of the relationship between the two Conventions, ${ }^{70}$ issues may have arisen under the CSBT Convention that would not arise under the LOS Convention. Thus, the question of whether catch limits previously established by the parties pursuant to the CSBT Convention were applicable to the Japanese experimental fishing program is not necessarily the same as the question of whether that program constituted a breach of the general conservation and management provisions of the LOS Convention.

(g) The arbitral tribunal determined that the dispute between the parties regarding the interpretation or application of the LOS Convention was the same dispute between the parties arising under the CSBT Convention.

(h) The dispute settlement clauses of the CSBT Convention:

(i) provide for submission of a dispute arising under the CSBT Convention to the ICJ or arbitration only with the consent of the parties;

(ii) include an annex setting out the arbitration procedure in the event the parties consent to arbitration; and

(iii) state that failure to reach agreement on reference to the ICJ or arbitration shall not absolve the parties to such a dispute of the responsibility of continuing to seek to resolve it by other peaceful means. ${ }^{71}$

(i) Japan had indicated willingness to arbitrate under the CSBT Convention. ${ }^{72}$

(2) The award decides the effect of another agreement on the compromissory clauses of the LOS Convention. The question of derogation from the compulsory jurisdiction provisions of a different treaty is to be determined with reference to that treaty. In this connection:

(a) The dispute settlement articles of the LOS Convention expressly address the effect of other agreements for the settlement of disputes concerning the interpretation or application of the LOS Convention.

(b) There are significant exceptions to compulsory jurisdiction under the LOS Convention.

\footnotetext{
7 Article 116(a) of the LOS Convention provides, inter alia: "All States have the right for their nationals to engage in fishing on the high seas subject to: (a) their treaty obligations ...." See also infra note 125.

${ }^{71}$ It seems likely that an empirical review would reveal that the first of the latter three characteristics is shared by a fair number of agreements, that the second does not necessarily follow in those agreements that mention arbitration but have the first characteristic, and that the third is unusual (especially in an article that begins by repeating the basic obligation of Article 33 of the UN Charter). In this connection one might consider the emphasis placed on the second and especially the third characteristics in paragraph 57 of the award (quoted below).

The tribunal observed, with respect to the third characteristic, that "this provision does not require the Parties to negotiate indefinitely while denying a Party the option of concluding, for purposes of both articles 281 (1) and 283, that no settlement has been reached." Award, supra note 15, para. 55. The tribunal also noted that the "terms of article 16 of the 1993 [CSBT] Convention [quoted supra note 20] do not expressly and in so many words exclude the applicability of any procedure, including the procedures of section 2 of Part XV" of the LOS Convention. Id., para. 56. Paragraph 57 of the award continues (footnotes omitted):
}

Nevertheless, in the view of the Tribunal, the absence of an express exclusion of any procedure in Article 16 is not decisive.... The ordinary meaning of [the] terms of Article 16 makes it clear that the dispute is not referable to adjudication by the International Court of Justice (or, for that matter, ITLOS), or to arbitration, "at the request of any party to the dispute" (in the words of UNCLOS Article 286). The consent in each case of all parties to the dispute is required. Moreover,.... [ $t$ ] he effect of th [e] express obligation to continue to seek resolution of the dispute by the listed means of Article 16(1) is not only to stress the consensual nature of any reference of a dispute to either judicial settlement or arbitration. That express obligation equally imports, in the Tribunal's view, that the intent of Article 16 is to remove proceedings under that article from the reach of the compulsory procedures of section 2 of Part XV of UNCLOS, that is, to exclude the application to a specific dispute of any procedure of dispute resolution that is not accepted by all parties to the dispute. Article 16(3) reinforces that intent by specifying that, in cases where the dispute is referred to arbitration, the arbitral tribunal shall be constituted as provided for in an annex to the 1993 Convention, which is to say that arbitration contemplated by Article 16 is not compulsory arbitration under section 2 of Part XV of UNCLOS but rather autonomous and consensual arbitration provided for in that CCSBT anneX.

${ }^{72}$ Award, supra note 15, para. 28. 
(c) Even the effect on the compulsory jurisdiction provisions of the LOS Convention may be limited (see next paragraph).

(3) The award decides the effect of an agreement regulating a particular highly migratory species on the compulsory jurisdiction clauses of the LOS Convention in relation to its provisions regarding high seas fishing for highly migratory species. The relationship between other agreements and other provisions of the LOS Convention may suggest a different effect on the compulsory jurisdiction clauses of the LOS Convention. In this connection:

(a) Especially with regard to high seas fisheries, the LOS Convention relies on agreements and institutional arrangements between the states concerned with fisheries in a particular area or a particular stock as the principal instrument for implementing its provisions regarding conservation and management of those fisheries. ${ }^{73}$ Such comprehensive reliance on implementing agreements does not characterize, at least to the same degree, many other aspects of the LOS Convention.

(b) Because coastal states may decline to litigate disputes regarding fisheries management in their exclusive economic zones under Article 297(3) of the LOS Convention, agreement between the concerned states may be the only reliable means for implementing Article 64's objective of conservation and management of highly migratory species throughout their migratory range, both within and beyond the exclusive economic zone. ${ }^{74}$

(c) Framing an arbitral award regarding conservation and allocation of a highly migratory species poses especially complex legal and practical problems where the parties to the arbitration do not include all the parties whose vessels are engaged in fishing for the stock. ${ }^{75}$

\footnotetext{
${ }^{73}$ Id., para. 29.
}

${ }^{74}$ The arbitral tribunal noted the problem posed by Article 297(3). In its words, "this is an important 'but' " qualifying compulsory jurisdiction under the LOS Convention. Id., para. 61. Australia and New Zealand had argued that this was not a problem in the instant case. Be that as it may, this problem is not negligible where the jurisdictional limitations of Article 297(3) are invoked either in the claim itself or in response to a counterclaim. There is an express duty to conserve highly migratory species both within the EEZ and on the high seas. If that duty is enforced only on the high seas, either its object may be frustrated or its implementation may transform a conservation principle into an allocational preference for coastal states that transcends the duty under Article 116 to conduct high seas fishing in a manner compatible with coastal state rights and interests in the EEZ.

Whether the solution is to decline to hear the case is a different matter. Where the applicant is not meeting its conservation duties in its own EEZ, it may confront the general principle that a party may not benefit from its own wrongdoing. But the critical conservation problems before a tribunal relate to the future. A variety of techniques are available to deal with those problems without dismissing the case. For example, a tribunal whose jurisdiction is restricted to high seas fishing may render a judgment or award that limits the respondent's high seas fishing on the condition that the applicant respect certain limitations within its EEZ, and that permits the respondent to return to the tribunal if the condition is not being fulfilled. The ITLOS provisional measures order in the instant case imposed limitations on all the parties, even though the applicants' fisheries for southern bluefin tuna are conducted in their respective EEZs. (The order does not discuss the jurisdictional issue this might pose, perhaps because the applicants did not invoke the jurisdictional limitations of Article 297(3).) The legal source of such authority at the provisional measures stage may be the duty of both parties not to aggravate or extend the dispute pendente lite and a tribunal's express right under Article 290(1) of the LOS Convention to prescribe provisional measures "to prevent serious harm to the marine environment." But surely it does not take extraordinary legal agility to find an adequate source of authority to frame a comparable, albeit conditional, remedy in a final judgment. Such a source might be found, for example, in the express conservation obligations of the coastal state and in the general principle articulated by Article 192 that states have an obligation to protect and preserve the marine environment. Moreover, even an arbitral tribunal may decide to permita party to reopen the proceedings in the event of a dispute concerning the implementation of its award regarding allocation of fishing rights. See Award in the Second Stage of Proceedings (Maritime Delimitation) (Erit./Yemen) (Dec. 17, 1999), at <http://www.pca-cpa.org>; W. Michael Reisman, Case Report: Eritrea-Yemen Arbitration (Award, Phase II: Maritime Delimitation), 94 AJIL 721 (2000).

${ }^{75}$ In cases before the IrLOS regarding the interpretation or application of the LOS Convention, all parties to the Convention are notified of the proceedings and have a right to intervene. LOS Convention, supra note 3, Annex VI, Art. 32. The IGJ might permit intervention under Article 62 of its Statute. Problems remain, however, if the third state is not party to the case. In the Libya/Malta case, the ICJ, having rejected Italy's petition to intervene, limited its judgment to areas not claimed by Italy. Continental Shelf (Libya/Malta), Application to Intervene, 1984 ICJ REP. 3 (Mar. 21), and Judgment, 1985 ICJ REP. 13 (June 3). In the East Timor case, the ICJ regarded the absence of Indonesia as crucial and rejected the application. East Timor (Port. v. Aust.), 1995 ICJ REP. 90 (June 30). 
(d) The Straddling Stocks Agreement ${ }^{76}$ is expressly designed to provide a more precise basis for implementing the provisions of the LOS Convention relevant to the instant case. It was negotiated under UN auspices at the urging of the 1992 UN Conference on Environment and Development (UNCED) and has been signed by the parties to the case and many other states. A significant number of states have already ratified the Agreement and it may enter into force shortly. ${ }^{77}$ The arbitral tribunal acknowledged that the Agreement provides for the application of the dispute settlement clauses of the LOS Convention to conservation and management agreements like the CSBT Convention. ${ }^{78}$ The fact that governments are now actively considering whether they desire such a result may have suggested to the arbitral tribunal that, at least for the moment, it was best to leave that decision to the treaty ratification process.

\section{Broader Implications}

One cannot predict whether another tribunal would regard all, some, or none of the foregoing grounds as constituting a rational basis for distinguishing the award in a future case. Needless to say, the decision as to which broad interpretations may be excluded depends on which, if any, of the grounds for distinguishing the award are adopted. The broader one's view of the ratio decidendiof the award, the more significant the issue of whether to agree or disagree in a future case.

The impact of the award in the future largely depends on the possibilities for construing the ratio decidendi of the award more broadly. The purpose is not to suggest that broader interpretations would be correct, but to illustrate the range and significance of potential decisions by other tribunals in future cases regarding the ratio decidendi and possible precedential effect of this award.

The determination that the "same dispute" arose under both the CSBT Convention and the LOS Convention was a crucial step in the award. Assuming arguendo that one regards this as a generally applicable basis for determining when the dispute settlement provisions of two instruments may be deemed to be mutually exclusive, the question of when the "same dispute" arises under two sources of obligation implicates a significant number of issues if some of those sources are subject to compulsory jurisdiction and others are not. Absent express language, what is the effect of bilateral or regional agreements on the dispute settlement provisions of the ICAO Convention, or those of the GATT and WTO agreements, or the optional clause of the ICJ Statute?

Type of dispute settlement clause that does not establish compulsory jurisdiction. The number of agreements between states that contain dispute settlement clauses that do not establish compulsory arbitration or adjudication is legion, ranging from provisions for consultation to provisions for mediation or conciliation to provisions for arbitration or adjudication by

\footnotetext{
7i Straddling Stocks Agreement, supra note 53.

${ }^{77}$ Both Canada and the United States have ratified the Agreement but have yet to become party to the LOS Convention. As of April 23, 2001, twenty-eight ratifications and accessions had been deposited of the required thirty. Italy and Luxembourg have indicated to the UN Secretary-General that their ratifications may not be effective pending the simultaneous deposit of instruments of ratification by all member states of the European Union. Status of the United Nations Convention on the Law of the Sea and Related Agreements as at 23 April 2001, at <http://www.un.org/Depts/los/status2001.pds (visited Apr. 23, 2001).

${ }^{78}$ Award, supra note 15, para. 71. Article 30 of the Straddling Stocks Agreement, supra note 53, provides, in part:
}

1. The provisions relating to the settlement of disputes set out in Part XV of the [LOS] Convention apply mutatis mutandis to any dispute between States Parties to this Agreement concerning the interpretation or application of this Agreement, whether or not they are also Parties to the Convention.

2. The provisions relating to the settlement of disputes set out in Part XV of the [LOS] Convention apply mutatis mutandis to any dispute between States Parties to this Agreement concerning the interpretation or application of a subregional, regional or global fisheries agreement relating to straddling fish stocks or highly migratory fish stocks to which they are parties, including any dispute concerning the conservation and management of such stocks, whether or not they are also Parties to the Convention. 
mutual consent. Should we distinguish among the most common formulations? ${ }^{79}$ For example, should we distinguish between a dispute settlement clause that provides only for consultation and one that provides for arbitration or adjudication by mutual consent? Both have the same effect with respect to jurisdiction under the agreement in which the clause appears: there is no jurisdiction to arbitrate or adjudicate absent consent specific to the dispute. Should the jurisdictional effect on another treaty differ depending on which of the two is used? If not, precisely what may be left of compulsory jurisdiction in a world where a dispute may well arise under any number of treaties?

Multiple sources of obligation. A careful analysis in a different context of the jurisdictional problem posed by multiple sources of obligation can be found in Judge Schwebel's dissent from the decision upholding jurisdiction in the Nicaragua case.$^{80}$ Assuming that the United States reservations to jurisdiction over disputes arising under multilateral treaties are given effect ${ }^{81}$ with respect to the UN Charter and the OAS Charter, both of which contain fundamental rules relevant to the challenges to the use of force made by Nicaragua in that case, the question was whether the Court could proceed solely on the basis of Nicaragua's customary law claims. The United States argued that "on analysis, all of Nicaragua's claimscustomary and treaty-based-are in substance the same. ${ }^{82}$ In Judge Schwebel's view, there was "broad but not necessarily complete substantive equivalence between the claims which Nicaragua makes under conventional and under customary international law"; he nevertheless had "some difficulty in seeing how the Court can proceed to adjudicate Nicaragua's claims if ... reliance on [the standards set forth in the multilateral treaties] is excluded." The Court itself sought to avoid the problem in its judgment on the merits (from which Judge Schwebel also dissented) by finding substantial identity between the standards of customary law regarding the use of force and those set forth in the treaties excluded from its jurisdiction.

The SBT award could be interpreted broadly to constitute an extension of Judge Schwebel's reasoning in the Nicaragua case to situations in which the dispute arises under one substantive treaty that does provide for compulsory jurisdiction, and another that does not. Such a rule might significantly limit compulsory jurisdiction in a world of proliferating treaties. Whether it is mandated by the express reasoning of the award or the setting of the case is a different matter.

Except in very limited circumstances, treaties may alter the obligations of the parties under customary law; that presumably is one of their most important functions. In the Nicaragua case, the question was whether it would make sense to render a judgment under customary law if the result conflicted with basic multilateral treaties establishing obligations fundamental to the public order. Moreover, the question was presented in its most trenchant form: Would it make sense for the principal judicial organ of the United Nations to render a judgment inconsistent with fundamental provisions of the UN Charter itself?

In the SBT case, the obligations of the parties arose from the substantive provisions of two treaties with the same object and purpose. The parties expressly provided for compulsory jurisdiction in one treaty but not the other. The $S B T$ award relies on the different dispute settlement provisions of the two treaties in question rather than any difficulties posed by multiple sources of substantive obligation. The reasoning of the award notes the complementary nature of the two treaties. Indeed, agreements such as the CSBT Convention are the political means through which the LOS Convention prescribes implementation of its

\footnotetext{
${ }^{79}$ Assuming arguendo that we do not limit the ratio decidendi of the award to the specific or most unusual characteristics of the dispute settlement provisions of the CSBT Convention.

${ }^{80}$ Nicaragua, supra note 25, Jurisdiction and Admissibility, at 5̄58, 613-16, paras. 85-90 (diss. op. Schwebel, J.).

${ }^{81}$ As the Court subsequently did in its decision on the merits.

${ }^{82}$ Nicaragua, supra note 25, Jurisdiction and Admissibility, at 614, para. 87 (diss. op. Schwebel, J.).

${ }^{83} I d$., para. 88.
} 
conservation and management norms with respect to highly migratory species. ${ }^{84}$ Moreover, exercising jurisdiction under the LOS Convention poses little risk of rendering a judgment that is not informed by the basic rules of the law of the sea now accepted by the overwhelming majority of states.

The LOS Convention expressly provides that a "tribunal having jurisdiction under this section shall apply this Convention and other rules of international law not incompatible with this Convention." ${ }^{85}$ Given the relationship between the LOS Convention and implementing arrangements, ${ }^{86}$ and the Convention's specific statement that the right of states for their nationals to engage in fishing on the high seas is "subject to . . their treaty obligations" as well as the relevant provisions of the Convention, ${ }^{87}$, ample basis can be found for attempting to avoid a substantive conflict by taking into account the obligations of the parties under the complementary agreement because it constitutes an implementation of their obligations under the Convention, or because it is incorporated by reference, or because of the customary law rule pacta sunt servanda. ${ }^{88}$ The legal bases for harmonization, however, may be less obvious where other treaties or other situations are at issue.

Is the LOS Convention unique? As the dissenting opinion of Sir Kenneth Keith makes clear, the issue is whether agreement of the parties to exclude otherwise binding compulsory jurisdiction clauses of a treaty must be express, or may be inferred. To rationally distinguish all or most other treaties establishing compulsory.jurisdiction from the LOS Convention with respect to this issue, it might well be necessary to make a determination, not obvious either on its face or from the reasoning of the award, that the reference to exclusion in Article 281 is unique to the LOS Convention: in other words, that its requirement that "the agreement between the parties does not exclude any further procedure" comprises something more than, or different from, a specific affirmation of the effect of certain generally applicable rules of the law of treaties, including the rule that states may ordinarily enter into agreements derogating from their obligations inter se under a multilateral treaty ${ }^{89}$

In the North Sea Continental Shelf cases, the fact that Article 12 of the Convention on the Continental Shelf expressly permits reservations to all articles except Articles 1-3 was deemed relevant to the determination that Article 6 was not declaratory of customary international law but that Articles 1-3 were. ${ }^{90}$ The $S B T$ award seems to lay out a one-way street: the fact that there are exceptions to compulsory jurisdiction, even if inapposite, is relevant to the strength accorded the commitment to compulsory jurisdiction in other respects. If, as the award seems to say, ${ }^{91}$ it may be more appropriate to infer derogation from compulsory jurisdiction clauses if those clauses do not apply to all disputes arising under the treaty in which they appear, and if that curious conceit ${ }^{92}$ is deemed relevant to a treaty such as the LOS Convention that provides for compulsory arbitration or adjudication of disputes with respect to a wide range of issues, the question becomes how one escapes application of that argument to the compulsory jurisdiction clauses of other treaties.

\footnotetext{
${ }^{84}$ See LOS Convention, supra note 3, Arts. 64(1), 118.

Id., Art. 293(1).

${ }^{86}$ See supra text at note 84.

${ }^{87}$ LOS Convention, supra note 3, Art. 116.

${ }^{8}$ Such a harmonizing interpretation accompanied submission of the LOS Convention to the U.S. Senate. See infra note 125.

${ }^{89}$ Vienna Convention on the Law of Treaties, supra note 38, Art. 41; LOS Convention, supra note 3, Art. 311.

${ }^{5 t}$ North Sea Continental Shelf (FRG/Den.; FRG/Neth.), 1969 ICJ REP. 3, para. 63 (Feb. 20).

${ }^{9}$ See Award, supra note 15, para. 62.

92 Many coastal states attached importance both to including high seas fishing within compulsory jurisdiction and to excluding fishing in the EEZ from compulsory jurisdiction. It is not apparent why either position should be regarded as weakening the other. It is particularly unclear why the latter should be regarded as weakening the former, because distant-water fishing states also gained the ability to contest unlawful coastal state interference with freedom of fishing on the high seas.
} 
The arbitral tribunal noted that the dispute settlement clauses of the CSBT Convention are largely drawn from the Antarctic Treaty. ${ }^{93}$ The parties to this arbitration, as well as other states that are party to the Antarctic Treaty, have also made declarations accepting the compulsory jurisdiction of the ICJ under Article 36(2) of its Statute. Assuming arguendo that these declarations contain no applicable reservations, does the ratio decidendi of the award apply to a challenge to the jurisdiction of the ICJ over a dispute between these parties that arises or, more to the point, also arises under the Antarctic Treaty? ${ }^{94}$ Although the text of the Antarctic Treaty clearly indicates that, absent specific consent, it is not an agreement to accept jurisdiction under Article 36(1) of the ICJ Statute, we are of course taught that paragraphs 1 and 2 of Article 36 constitute separate bases of jurisdiction. Even so, in addressing distinct bases of jurisdiction under separate paragraphs of the same article of the same instrument, on what grounds do we distinguish the conclusion of the award that dispute settlement clauses that expressly address disputes arising only under one treaty limit jurisdiction under the compromissory clauses of another treaty?

What would the result be if the $S B T$ dispute had been brought before the ICJ, with jurisdiction predicated on the declarations of the parties under the optional clause? Japan indicated to the arbitral tribunal that it would have objected to jurisdiction in the ICJ as well, "on grounds of reservations to the Optional Clause." ${ }^{.55}$ If the same objections successfully made before the arbitral tribunal were proffered to the ICJ, on what grounds would one distinguish the merits of the latter arguments before the ICJ? ${ }^{96}$ While the dispute settlement provisions of the CSBT Convention make no reference to those of the LOS Convention, like those of the Antarctic Treaty they do refer expressly to the ICJ. What would the Court make of its predecessor's decision in the Electricity Co. case? ${ }^{97}$

\footnotetext{
${ }^{93}$ See supra note 58. An analysis of the negotiating history of the Antarctic Treaty might reveal that the principal reason for the absence of compulsory jurisdiction in the Treaty does not relate to the positions of any of the parties to the dispute. See, e.g., supra note 43 (regarding the USSR's regular opposition to the inclusion of compulsory jurisdiction clauses in major multilateral treaties). Is uncertainty as to whether the same result might have been reached even absent Soviet opposition a sufficient reason to impose the effect of such opposition on the compromissory clauses of other treaties?

${ }_{94}$ The Antarctic Treaty specifically refers to the ICJ. Unlike the LOS Convention in the instant case, the UN Charter may not in itself constitute a separate source of obligation with respect to the particular issues. As in the Nicaragua case, it might make no sense to render a judgment under customary law that conflicts with the obligations of the parties under the Antarctic Treaty. For these reasons, one might conclude that the case for reaching the same result with respect to the optional clause as was reached in the award is stronger.

${ }^{95}$ Award, supra note 15, para. 39(c).

${ }^{96}$ While Japan's declaration under the optional clause excludes disputes "which the parties thereto have agreed or shall agree to refer for final and binding decision to arbitration or judicial settlement," the declarations of Australia and New Zealand exclude disputes "in regard to which the parties thereto have agreed or shall agree to have recourse to some other method of peaceful settlement." The latter declarations would seem to raise analogous issues regarding the effect of both the CSBT Convention and the LOS Convention, with the addition of an intriguing problem of possible mutual renvoi between the declarations and Article 281 of the LOS Convention. Declarations Recognizing as Compulsory the Jurisdiction of the Court, at <http://www.icj-cij.org/icjwww/ ibasicdocuments.htm>.

${ }^{97}$ Cesare Romano raises this issue in a forthcoming article, where he discerns a certain tension between the reasoning of the $S B T$ award and that of the PCIJ in concluding that a subsequent treaty between the parties for submission of disputes to the Court did not supersede or qualify the Court's jurisdiction under the optional clause pursuant to prior declarations of the parties. See Electricity Co. of Sofia and Bulgaria, Judgment, $1939 \mathrm{PCI}$ (ser. A/B) No. 77, at 62 . Finding such jurisdiction, the Court concluded that there was "nojustification for holding that ... [the parties] intended to weaken the obligations which they had previously entered into with a similar purpose, and especially where such obligations were more extensive than those ensuing from the Treaty." Id. at 76 . It reached this conclusion notwithstanding the fact that the treaty was concluded later in time, that it contained a comprehensive reference to disputes mentioned in Article 36 of the Court's Statute, that it included specific preconditions regarding litigation in municipal courts that the Court determined were not satisfied, and that Belgium's optional clause declaration contained an exception "in cases where the Parties have agreed or shall agree to have recourse to another method of pacific settlement." Id. at 74-76, 78-81. It should be noted, however, that the respondent, although it contested jurisdiction, specifically stated that the treaty "in no way suspended the operation of the optional clause" and that the treaty's provisions "simply reinforce and do not set aside the obligation resulting from the optional clause." Id. at 75-76. The Court emphasized that the parties were in agreement in this regard. Id.

Although the matter is not addressed, the painstaking effort to discern intent to supersede in the SBT award is in some ways reminiscent of Judge Hudson's dissent in the Electricity Co. case. See id. at I18 (diss. op. Hudson, J.).
} 
If the award is relevant only to the LOS Convention, is it relevant to more than fishing disputes? When does the same dispute arise under another treaty? Annex 47 to Japan's memorial contained an elaborate tabulation of agreements relating to the sea and their treatment of dispute settlement. ${ }^{98} \mathrm{~A}$ large number of those agreements contain dispute settlement clauses that do not provide for compulsory and binding third-party settlement. The arbitral tribunal invoked that fact in support of its conclusion..$^{99}$ Most of these agreements do not indicate that their purpose is to implement principles contained in the LOS Convention (or even mention the Convention), but an increasing number do refer to the Convention, either expressly or by implication. None expressly excludes compulsory procedures under the LOS Convention regarding the interpretation or application of that Convention. A fair number of these agreements relate to matters that are unlikely to be the subject of disputes concerning the interpretation or application of the LOS Convention. A fair number also relate to matters such as maritime boundary delimitation and fishing in the EEZ that are not necessarily subject to compulsory jurisdiction under the LOS Convention. The parties to some of these agreements include states that are not party to the LOS Convention and therefore have not accepted compulsory jurisdiction under that Convention. It is nevertheless apparent that were the ratio decidendi of the arbitral award to be read broadly to apply to other agreements and treated as persuasive precedent by other tribunals, it would unquestionably limit the effect of Article 286 in ways that are both significant and difficult to predict. ${ }^{100}$

One of the achievements of the LOS Convention is that virtually all marine sources of marine pollution are subject to a duty by the state with jurisdiction over the relevant activitybe it the flag state or the coastal state-to enforce minimum international safety and pollution standards. ${ }^{101}$ Many of these standards emerge in treaties and other instruments adopted by the International Maritime Organization or negotiated under its auspices. The duty to comply with these standards is subject to compulsory jurisdiction under Article 286 of the Convention. ${ }^{102}$ Particularly with respect to those formulated in the last quarter century, it can be argued that the standards were adopted with a view to implementing the environmental duties set forth in the LOS Convention. ${ }^{103}$ A dispute may arise as to whether a state's action conforms to the relevant international standard. What is the effect of this award where the standard in question emanates from an instrument that contains dispute settlement provisions but does not itself provide for compulsory jurisdiction ${ }^{104}$ Is the dispute the same under both instruments?

\footnotetext{
${ }^{99}$ The annexes to the memorials are not available on the ICSID Web site. I wish to express my appreciation to counsel for Japan for supplying a copy.

${ }^{5}$ Award, supra note 15, para. 63.

${ }^{169}$ The applicants put the point more forcefully: they argued that if Japan is right, the provisions of the Convention for mandatory dispute settlement are "a paper umbrella which dissolves in the rain." Id, para. 41 (k).

${ }^{101}$ LOS Convention, supra note 3, Arts. 21(4), 39, 54, 58(2), 60(5), 94(5), 208(3), 209(2), 210(6), 211 (2); see also id.,Arts. 60(3),61(3), 119(1) (a), 207(1),212(1) (obligation to take into account international standards). The environmental provisions of the Convention do not apply to warships and other ships and aircraft entitled to sovereign immunity. Id., Art. 236.

${ }^{102}$ Under Article 297(1) (c), even the coastal state's duty, for example with respect to dumping, is subject to compulsory jurisdiction for violation of "specified international rules and standards for the protection and preservation of the marine environment."

${ }^{103}$ See LOS Convention, supra note 3, Arts. 43, 192, 194(1), 197, 199, 200, 201, 204, 207(4), 208(5), 210(4), $211(1), 212(3)$.

${ }^{104}$ For example, Article 210(6) of the LOS Convention requires states to respect global rules and standards regarding dumping. These are to be found in the Convention on the Prevention of Marine Pollution by Dumping of Wastes and Other Matter, Dec. 29, 1972, 26 UST 2403, 1046 UNTS 120. Article X of the Convention requires the parties "to develop procedures for the assessment of liability and the settlement of disputes regarding dumping." The 1996 Protocol to the Dumping Convention establishing compulsory jurisdiction is gaining significant adherence but is not yet widely ratified. In considering the effect of the award, one could regard the compulsory jurisdiction provisions of the LOS Convention as themselves constituting partial execution of the obligation in Article $\mathrm{X}$ of the Dumping Convention.
} 
In addition to enforceable flag state duties, the Convention accommodates coastal state environmental interests, while protecting navigation rights and freedoms in straits, archipelagic sea lanes, and the exclusive economic zone, by according coastal states carefully circumscribed powers to enforce generally accepted international pollution standards against foreign ships. ${ }^{105}$ To protect navigation, the exercise of these powers is subject to compulsory jurisdiction under Article 286 of the Convention, and that jurisdiction is not excluded by section $3 .^{106}$ The same questions posed in the previous paragraph can arise in this context as well. Is it relevant that neither maritime states nor coastal states would have arrived at a consensus on the carefully balanced provisions of the Convention regarding pollution from ships unless both flag state duties and coastal state rights were subject to compulsory jurisdiction?

There are thus far-reaching effects to determining that the "same dispute" arises under both the LOS Convention and another treaty, and that, when it does, the dispute settlement clauses of the other treaty, absent an express indication to the contrary, also apply to disputes concerning the interpretation or application of the LOS Convention. For one thing, provisional measures would presumably not be available from the ITLOS pending the constitution of an arbitral tribunal under another treaty to adjudicate the "same dispute."107 Even treaties that do contain compulsory arbitration clauses would therefore have some derogating effect under a broad reading of the award, an effect that is by no means inconsequential, for example, in conservation cases. ${ }^{108}$ The absence of timely provisional remedies can itself increase the likelihood of resort to self-help, which could destabilize the regimes established by the LOS Convention or other general regulatory treaties. Herein lies a particular irony because the arbitral tribunal went out of its way to note the salutary effects of the provisional measures order in narrowing the gap between the parties in the instant case. ${ }^{109}$

If the award were read broadly, problems in sorting out the relationship between the dispute settlement clauses of different regulatory treaties that do not expressly refer to each other would be addressed neither in light of the accumulated learning reflected in private international law rules that have long had to deal with and accommodate both a multiplicity of fora and a multiplicity of sources of obligation, ${ }^{110}$ nor on some pragmatic case-by-case basis

${ }^{105}$ LOS Convention, supra note 3 , Arts. 42(1) (b), 54, 211(5), 221(3)-(6), 233. The regulatory powers of the coastal state with respect to innocent passage in the territorial sea are broader, but even here the coastal state must conform to generally accepted international standards in prescribing standards for construction, manning, equipment, and design. Id., Art. 21(2).

${ }^{106} I d$., Art. 297(1) (a). The right under Article 298(1) (b) to exclude compulsory jurisdiction over law enforcement activities of the coastal state relates only to its regulation of fisheries and scientific research, not to its enforcement with respect to pollution from ships.

${ }^{107}$ Article 290(5) applies pending the constitution of an arbitral tribunal "under this section," namely section 2. Arbitration under another instrument would not arise under section 2 (unless the other instrument incorporated section 2). Article 282, which contains the relevant choice-of-forum provision, itself appears in section 1 , not section 2.

${ }^{108}$ This is illustrated by the substantial attention devoted to provisional measures in the Straddling Stocks Agreement. See infra note 145.

${ }^{109}$ Arvard, supra note 15, paras. 67-69.

${ }^{110}$ Needless to say, analogies to private international law or municipal law must be approached with circumspection. Whether they provide a useful aspirational benchmark is nevertheless a relevant question.

To take but one example, there is a general assumption in private international law that somejudicial or arbitral tribunal has, or ought to have, compulsory jurisdiction over a legal claim. That assumption may affect decisions regarding jurisdiction. See, e.g., U.S. FED. R. CrV.P. 4(k)(2). The U.S. Supreme Court has left open the question of whether the same limitations on personal jurisdiction imposed by the constitutional requirement of due process apply "when no other forum is available to the plaintiff." Shafferv. Heitner, 433 U.S. 186, 211 n.37 (1977). Similar perspectives may also have influenced the Court to confirm broad (some might say "exorbitant") bases of general jurisdiction in principle. See Burnham v. Super. Ct. of Cal., 495 U.S. 604 (1990).

That assumption may have other consequences in municipal law. The absence or exclusion of compulsoryjurisdiction is not ordinarily regarded as relevant to the intent of states to conclude a legally binding agreement under public international law. However, a municipal court faced with a comprehensive covenant not to sue, applicable to all provisions of a private agreement containing the covenant, might conclude that the express exclusion of all 
perhaps analogous to common-law rules of forum non conveniens. They would be resolved by a flat jurisdictional conclusion that because the dispute is the same, the compromissory clauses of the LOS Convention do not apply.

The LOS Convention expressly requires that civil aircraft in transit passage of straits observe the Rules of the Air established under the 1944 Convention on International Civil Aviation, and that state aircraft normally observe those rules. ${ }^{111}$ What remedies are available to a straits state if this obligation is violated? The ICAO Convention is one of the world's most widely ratified treaties. Although it assumes the existence of a law of the sea, it was obviously not negotiated with the LOS Convention specifically in mind. ${ }^{112} \mathrm{On}$ its face, the LOS Convention appears to afford the straits state the right to invoke compulsory jurisdiction. ${ }^{113}$ But the ICAO Convention contains its own, somewhat unusual, partially political, and arguably awkward dispute settlement procedures that are both apparently compulsory and little used, and that in any event do not apply to state aircraft. ${ }^{114}$ Possibly, the dispute would be best addressed under ICAO dispute settlement procedures. However, if the award's conclusion that the "same dispute" arose under two different regulatory treaties is to be construed to extend to this situation with the same consequences, that would not be the question: broad application of the precedent would automatically cut off the compulsory procedures of the LOS Convention under either Article 281 or Article 282.

What of mixed issues in the "same dispute"? Let us suppose that a coastal state adopts and proposes to enforce pollution regulations regarding ships navigating through its exclusive economic zone. Let us suppose further that a flag state questions whether, as required by Article 211(5), those regulations conform to "generally accepted international rules and standards established through the competent international organization or general diplomatic conference." Two issues would be posed: (1) whether the relevant international rules and standards are "generally accepted," and (2) whether the regulations conform to them. The first issue arises exclusively under the LOS Convention. The second could arise under both the Convention and the instrument from which the international rules and standards emanate. That instrument might well contain its own dispute settlement clauses. Is the award's precedential effect limited to cases in which all the issues arising under the Law of the Sea Convention also arise under the other agreement? If so, skillful counsel might well be able to circumvent it. If not, precisely how does a jurisdictional approach apply to such cases?

Not all parties to the LOS Convention have exercised their option under Article 298 to file declarations excluding disputes concerning military activities. In addition to numerous specifically directed provisions expressly or implicitly having the same import, ${ }^{115}$ the General Provisions of the LOS Convention substantially reproduce the prohibition on the use or

judicial, arbitral, or equivalent third-party remedies for breach is inconsistent with the intent to create a legally binding contract under private law. Accordingly, it might declare the entire agreement void or unenforceable. Alternatively, and of potentially more interest to students of international law, it might construe the covenant not to sue narrowly, or decide that the covenant is unenforceable in whole or in part, or conclude that the covenant is irrelevant because the "same dispute" arises underanother agreement that is subject to compulsoryjurisdiction.

${ }^{111}$ LOS Convention, supra note 3, Art. 39(3) (a).

${ }^{112}$ For an analysis of the relationship between the Conventions, see Michael Milde, The United Nations Convention on the Law of the Sea-Possible Implications for International Air Law, 8 ANNALS AIR \& SPACE L. 167 (1983); Bernard H. Oxman, Overflight Under the 1982 UN Convention on the Law of the Sea: Transit of Straits and Archipelagic Waters by Military Aircraft, PROC. 3D INT'L L. SEMINAR, PUB. INT'L AIR L. 39 (Singapore 1999), and 4 SINGAPORE J. INT'L \& COMP. L. (2000).

${ }^{119}$ While states have the option to file declarations excluding military activities from compulsory jurisdiction under Article 298 of the LOS Convention, many have not done so.

${ }^{114}$ Convention on International Givil Aviation, Dec. 7, 1944, Arts. 3, 84-88, 61 Stat. 1180, 15 UNTS 295.

${ }^{115}$ See, e.g., LOS Convention, supranote 3, Art. 19(2) (a) (innocent passage); Arts. 39(1) (b) \& 54 (transit passage of straits and archipelagic sea lanes passage); Arts. 88, 141, 143(1), 147(2)(d), 155(2), 240(a), 242(1), 246(3) (peaceful purposes). 
threat of force contained in Article 2, paragraph 4 of the UN Charter. ${ }^{116}$ Does a broad reading of the award mean that states are to be denied compulsory jurisdiction under the Convention with respect to such provisions because the UN Charter contains an elaborate ICJ Statute dealing with dispute settlement that contemplates compulsoryjurisdiction only when the parties have so agreed or declared? ${ }^{117}$ Would we reach a reductio ad absurdum if the ICJ's jurisdiction in such a case were itself predicated on declarations of the parties under Article 287 of the LOS Convention?

\section{INTERESTS POTENTIALLY AFFECTED}

Do the possible future applications of the award further the general foreign policy interests, overall maritime interests, and long-range fisheries interests of the apparent victor? Ultimately, only Japan can answer the question. A variety of competing views and priorities may influence how Japan perceives its interests at any given time. ${ }^{118}$ It may nevertheless be useful to consider how one might develop an argument that the ratio decidendiof this award, unless strictly confined to the particular facts, does not serve Japan's interests. Of course, many of these interests are shared by others, often many others.

The basic argument is that the substantive model of the LOS Convention and its compulsoryjurisdiction provisions reflects fundamental values and interests in international affairs in general and the law of the sea in particular. The arbitral award, if it broadly influences other tribunals to pursue only a procedural model, substantially weakens what Japan sought, and has abiding interests in receiving, from Article 286 and, consequently, from the LOS Convention as a whole. ${ }^{119}$ That argument depends neither on the proposition that it was in Japan's interests to lose the case, nor on the view that Japan would or should have otherwise lost. It focuses solely on the possible prospective effects of the reasoning articulated in the award.

\section{Interests in a Peaceful Global Order}

A peaceful international order in which law and legal process are brought to bear on disputes is a basic characteristic of the world Japan and other states seek to build by word and deed. Although unquestionably preferring negotiation and eschewing litigation, Japan, like other states, has demonstrated a clear-headed understanding that at some point the choice is not between negotiation and litigation, but between litigation and less orderly forms of conflict when governments prove unable to manage or live with their disagreements. Japan has set an admirable example by accepting the compulsory jurisdiction of the ICJ under the

${ }^{116}$ Article 301 of the LOS Convention provides:

In exercising their rights and performing their duties under this Convention, States Parties shall refrain from any threat or use of force against the territorial integrity or political independence of any State, or in any other manner inconsistent with the principles of international law embodied in the Charter of the United Nations.

${ }^{117}$ It can be argued, of course, that the purpose of the ICJ Statute transcends the UN Charter, and is designed to embrace all or most disputes under other treaties and customary law. In this connection one may note that Article 288(2) of the LOS Convention provides: “A court or tribunal referred to in article 287 shall also have jurisdiction over any dispute concerning the interpretation or application of an international agreement related to the purposes of this Convention, which is submitted to it in accordance with the agreement."

In the case of the ITLOS, this expressly includes entities other than states parties. LOS Convention, supra note 3, Annex VI, Art. 20 (2). In addition, echoing Article 36(1) of the ICJ Statute, Article 21 of Annex VI provides: "The jurisdiction of the Tribunal comprises all disputes and all applications submitted to it in accordance with this Convention and all matters specifically provided for in any other agreement which confers jurisdiction on the Tribunal."

${ }^{118} \mathrm{I}$ am in no sense an expert on Japan. But for many years I have been privileged to observe, with great respect, the development and articulation of Japanese foreign policy, especially with regard to the law of the sea.

119 “[C]'est l'avenir même du régime général de la mer qui est en cause dans cette affaire." Weckel \& Helali, supra note 15 , at 1038 . 
optional clause. It has supported compulsory and binding dispute settlement in other fora and has accepted such settlement under a variety of treaties, even when the choice is optional. From this perspective, Article 286 of the LOS Convention reflects fundamental values regarding the nature of the global order, and broad derogation from that article is to be avoided.

\section{General Interests in the Law of the Sea}

Expressly criticizing the optional-protocol approach of the 1958 conventions on the law of the sea, Japan was among the very first states to support the inclusion of compulsory and binding dispute settlement as an integral part of a new convention. ${ }^{120}$ This reflects not only general foreign policy views, but specific interests in a stable order for the oceans.

Japan is one of the world's great maritime and trading nations. Its economy and prosperity are overwhelmingly dependent on far-flung trade carried by ships and aircraft, as well as telecommunications by undersea cable linking all parts of the globe. Both its security and its economic interests are furthered by the global mobility of friendly naval and air forces. Japan is also one of the world's largest harvesters and consumers of marine fisheries. To a significant degree, it shares the general interest in ensuring global protection of the marine environment.

If there was an underlying "evil sought to be remedied" by a new LOS convention from the perspective of maritime nations, it was the instability wrought by unilateralism. That instability threatened all interests in communications, be they economic or military. It threatened all but the most localized and haphazard efforts to deal with marine pollution. It threatened established fishing interests. At times it even threatened the peace.

By becoming party to the LOS Convention, Japan formally (if reluctantly) accepted significant limitations on its distant-water fishing fleet in a huge new exclusive economic zone for the sake of achieving a new order that promised to bring unilateralism under control. It presumably did so primarily for the benefit of its other interests, including navigation and communications, environmental protection, and international order at sea. This choice is reflected not only in the substantive provisions of the LOS Convention protecting navigation and communications and the marine environment, but also in the dispute settlement articles. Thus, all coastal state actions, including law enforcement actions, that allegedly violate navigation and communications rights under the LOS Convention are subject to compulsory jurisdiction under Article 286; they are not excluded by section 3 . The same holds true of coastal state duties to implement specified environmental standards. It is perhaps ironic from the perspective of maritime nations like Japan that the arbitral award reveals no concern regarding the potentially prejudicial implications of the decision for the protection of the very interests to which those nations ultimately accorded priority over distant-water fishing interests.

The system of compulsory and binding settlement of disputes was central to maintaining and, through evolving judicial interpretations, developing the new order represented by the new Convention. Here, and to a significant degree here alone, lay a plausible alternative to unilateral enforcement of unilateral claims of right: compelled by interest or political pressure to act, a state could unilaterally seize an international tribunal and request legally binding vindication of its claims, including legally binding provisional measures.

From this perspective, Article 286 reflects underlying interests in promoting order and combating unilateralism at sea. It is open to serious question whether those interests are furthered by the view of the arbitral tribunal that its conclusion is reinforced by the large number of agreements relating to the sea that do not provide for compulsoryjurisdiction. ${ }^{121}$

\footnotetext{
${ }^{120}$ See supra note 39.

${ }^{121}$ Award, supra note 15, para. 63.
} 
This view implies that these agreements may also override Article 286, and therefore weaken what states can expect from that article. The question, let us recall, is not whether the obligations of states under these agreements are subject to compulsoryjurisdiction, but whether these agreements, notwithstanding the absence of an express provision to that effect, will be interpreted to block compulsory jurisdiction under the LOS Convention with respect to obligations arising under that Convention.

The greatest threat to the stability of the law of the sea since the conclusion of the LOS Convention in 1982 stemmed from the deepening crisis over high seas fishing for the same stocks that are subject to coastal state management and economic priorities when found within the exclusive economic zone. In one form or another, states such as Argentina, Canada, and Chile made unilateral claims beyond 200 miles designed at least to draw attention to the problem. Canada arrested a Spanish fishing vessel beyond 200 miles in a case that found its way to the ICJ. The United States and Russia darkly warned that, if their problems in the Bering Sea were not resolved, political pressures might force them to take direct action. ${ }^{122}$

It may be that high seas fishing states made the concessions they did in the Straddling Stocks Agreement solely to calm the waters and salvage what they could of their high seas fishing interests. The broader threat was that the entire edifice of stability created by the LOS Convention might collapse. If, unlike the earlier implementing agreement regarding deep seabed mining, the one concerning high seas fishing does not require that its parties be party to the LOS Convention, the intent was presumably to make it as easy as possible for states such as Canada and the United States that were not yet party to the LOS Convention to join the Straddling Stocks Agreement quickly. ${ }^{123}$

Sophisticated students of the law of the sea understand that, notwithstanding its interests as a global maritime power, the United States has caused a significant degree of instability in the law of the sea by making unilateral claims. The Truman Proclamations of 1945 are a famous example. These students also understand that it can be particularly difficult to persuade members of the U.S. Congress to afford priority to arguments about customary international law over purely local pressures from their constituents; members of Congress are well aware that their own lack of restraint, particularly if popular with other coastal states, can rather quickly change the content of customary law.

Ultimately, stability in the law of the sea can be achieved only by bringing most of the remaining nonparties, including the United States, into the LOS Convention itself. Does this award promote the objective of universal ratification of the LOS Convention? The very uncertainty regarding the scope of the limitations on compulsory jurisdiction under the Convention that may be inferred from the award suggests that it may not do much, if anything, to reassure those who are nervous about compulsory jurisdiction in principle. But the award could trouble those who desire compulsory jurisdiction for conservation, environmental, or navigational reasons. It could also weaken the position of those who argue that compulsory jurisdiction is one of the significant benefits of becoming party to the LOS Convention that cannot be obtained solely by reliance on the position that the Convention is generally declaratory of customary law.

\footnotetext{
${ }^{122}$ The problem was addressed by the Convention on the Conservation and Management of Pollock Resources in the Central Bering Sea, June 16, 1994, S. TREATY DOC. No. 103-27 (1994), 34 ILM 67 (1995), which is in force for China, Japan, South Korea, and the two coastal states. The preamble to the Convention refers to the adoption of the LOS Convention, and Article XIII provides for consultation regarding settlement of disputes.

${ }^{123}$ This approach may have been a strategic error by Japan and the European Commission related to the fact that narrow interests dominated their delegations at the time. Had they insisted that, at least after an interim period, only parties to the LOS Convention could be party to the Straddling Stocks Agreement, both Canada and the United States might already be party to both treaties. It remains possible, of course, that formal acceptance of the Straddling Stocks Agreement by the European Union and Japan could be coordinated with formal acceptance of the LOS Convention by Canada and the United States.
} 
The underlying attitude of the arbitral tribunal regarding the relationship between the Convention and specific fisheries agreements does not appear to be consistent with the interpretation of the executive branch that accompanied the submission of the LOS Convention to the U.S. Senate. Curiously, the tribunal seems not to have been informed of it. ${ }^{124}$ According to this interpretation, pursuant to the compulsory jurisdiction provisions of the LOS Convention, the resolution of disputes concerning the interpretation and application of the conservation and management provisions of the Convention applicable to high seas fishing may be informed by the particular limitations set forth in agreements and instruments implementing those provisions. ${ }^{125}$ One of the instruments cited contains dispute settlement provisions that provide for consultation. ${ }^{126}$ It takes little imagination to realize that this interpretation might appeal to fishermen and environmentalists from whom members of the Senate might seek advice. Since an even stronger result is achieved under the dispute settlement provisions of the Straddling Stocks Agreement anyway, ${ }^{127}$ maritime and distantwater fishing states would seem to gain little, and might lose a great deal, from the risk of complicating matters even more in the U.S. Senate, where the Convention has yet to be acted on.

Needless to say, compulsory jurisdiction is not the only tool for combating unilateralism. The process by which the LOS Convention itself was developed-namely, multilateral negotiations emphasizing accommodation and consensus-played a very important role in both obviating the need for and delegitimating unilateralism. The negotiation of the Straddling Stocks Agreement was the second successful test of this approach since the completion of the Convention, and the one directly relevant to the main problem of unilateral claims by coastal states that had yet to become party to the Convention.

The question is not whether the parties to the arbitration were already bound by the Straddling Stocks Agreement; as signatories that had yet to ratify the Agreement, they were not bound, and accordingly had yet to agree that the LOS Convention is to be applied in the way the Agreement says it is to be applied. ${ }^{128}$ The question is the influence of the Straddling Stocks Agreement, given its pedigree and its purpose, where reasonable arguments can otherwise be made that the proper interpretation or application of the LOS Convention accords with the result in the Agreement. How are the interests of Japan and other states in legitimating the multilateral negotiating process on the basis of accommodation and consensus advanced by an award that reaches out to arrive at precisely the reverse result of that contemplated by the Straddling Stocks Agreement?

Article 30(2) of the Straddling Stocks Agreement applies the entire dispute settlement system of Part XV of the Law of the Sea Convention, mutatis mutandis, to "subregional, regional or global fisheries agreements relating to straddling fish stocks or highly migratory

124 See MESSAGE FROM THE PRESIDENT, supra note 4.

${ }^{12}$ The commentary accompanying the president's message states:

Fishing beyond the EEZ is subject to compulsory, binding arbitration or adjudication. This will give the United States an additional means by which to enforce compliance with the Convention's rules relating to the conservation and management of living marine resources and measures required by those rules, including, for example, the prohibition in article 66 on high seas salmon fishing, the application of articles 63(2) and 116 in the Central Bering Sea in light of the new Pollock Convention, and the application of articles 66, 116 and 192 in light of the United Nations General Assembly Resolutions creating a moratorium on large-scale high seas driftnet fishing.

Id. at 51 (emphasis added).

${ }^{126}$ The Bering Sea Pollock Convention, supra note 122.

${ }^{127}$ The U.S. view is reflected in Article 30(5) of the Straddling Stocks Agreement, quoted in note 145 infra, and of course extended in the direct application of the compulsory dispute settlement provisions of the LOS Convention to subregional, regional, or global fisheries agreements relating to straddling fish stocks or highly migratory fish stocks. See supra note 78.

${ }^{128}$ Since they were signatories, a question is nevertheless posed regarding the impact of Article 18 of the Vienna Convention on the Law of Treaties, supra note 38. 
fish stocks." ${ }^{\text {129 }}$ Just because Part XV carries section 1, including Article 281, with it, however, does not mean that the result under the Straddling Stocks Agreement would necessarily be the same as that reached in the instant case. The underlying question would no longer strictly be one of dispute settlement provisions of two different treaties. Part XV of the LOS Convention is in effect incorporated by reference into both the Straddling Stocks Agreement and the agreement in question.

This incorporation provides an explicit benchmark against which the effect of dispute settlement provisions in other agreements may be ascertained. There is no doubt that the Straddling Stocks Agreement itself emerged out of difficulties in attempts to conclude and implement agreements on high seas fishing. It adds important new substantive and procedural elements to the law of marine fisheries, including Article 30(2). Any but the most cursory study of the Agreement and its origins reveals that the application of compulsory jurisdiction, including provisional measures, to high seas fishing is the purpose of Article 30(2). ${ }^{130}$

The entry into force of an express agreement to apply Part XV to "agreements relating to straddling fish stocks and highly migratory fish stocks" presumably constitutes either the amendment of a prior agreement relating to such stocks, applicable to the parties to both, or a subsequent agreement between those parties regarding the application of their prior agreement. ${ }^{131}$ At least to the extent that the dispute settlement clauses of the prior agreement did not provide for compulsory jurisdiction, they would be overridden. ${ }^{132}$

The parties to the Straddling Stocks Agreement are free to include other provisions regarding dispute settlement in a subsequent agreement relating to straddling fish stocks or highly migratory fish stocks. Doing so might pose a conflict between the "later in time" rule and the objectives of Article 30(2) of the Straddling Stocks Agreement. Whether by virtue of the interpretive canon that the specific governs the general, or otherwise, the express provisions of Article 30(2) suggest that a higher degree of specificity in subsequent fisheries agreements would be required to evidence agreement to derogate from compulsory jurisdiction under Part XV. ${ }^{133}$ During the potentially lengthy transitional period in which fisheries agreements are concluded after some of their parties havejoined the Straddling Stocks Agreement but before others have done so, there would also be a question of how to apply the later-in-time rule even if apposite. One hopes that lawyers advising governments would

${ }^{129}$ See supra note 78.

${ }^{130}$ See supra note 78 and infra note 145. The effect of paragraphs 3 and 4 of Article 8 of the Straddling Stocks Agreement is that

[w] here a subregional or regional fisheries management organization or arrangement has the competence to establish conservation and management measures for particular straddling fish stocks or highly migratory fish stocks,....

... [o]nly those States which are members of such an organization or participants in such an arrangement, or which agree to apply the conservation and management measures established by such organization or arrangement, shall have access to the fishery resources to which those measures apply.

It would be extraordinary to conclude that this means the Straddling Stocks Agreement requires states (on pain of being bound by the decisions anyway) to join an organization or arrangement that excludes compulsory jurisdiction in derogation of the Straddling Stocks Agreement itself.

${ }^{131}$ See Vienna Convention on the Law of Treaties, supra note 38, Art. 31 (3) (a). Article 30(2) of the Straddling Stocks Agreement refers to "agreement[s] relating to straddling fish stocks or highly migratory fish stocks," and not merely to those that implement the Straddling Stocks Agreement. It thus would appear to apply in principle to both existing and future agreements.

${ }^{132}$ Careful consideration of the dispute settlement provisions of a particular prior agreement might also reveal the possibility for harmonizing them with the introduction of compulsoryjurisdiction under the Straddling Stocks Agreement. For example, with specific reference to the CSBT Convention, ratification of the Straddling Stocks Agreement could itself be regarded as an execution of the obligation of the parties to continue to seek means to resolve their disputes under Article 16 of the CSBT Convention, quoted supra note 20 . A similar result could be reached under dispute settlement provisions of existing agreements calling for consultation. See supra note122.

${ }^{133}$ See supra note 130. 
seek to ensure that, whatever the intent of the parties, it is clearly and expressly stated in new agreements relating to straddling stocks and highly migratory stocks. ${ }^{134}$

The arbitral tribunal itself appears to have believed that the jurisdictional problems posed by the case before it would be essentially resolved by the Straddling Stocks Agreement. ${ }^{135}$

\section{Fishing Interests}

It can be argued that the practical effect of the $S B T$ award is to allow high seas fishing to continue while precluding direct enforcement of the flag state's concomitant duty to conserve and manage living resources. That conclusion is not necessarily correct. If it is correct, it poses other problems. The issue is not addressed in the award.

What if parties to a regional fisheries agreement like the CSBT Convention interpret it to permit them, either directly or as a countermeasure, to take enforcement measures beyond the EEZ with respect to foreign fishing they believe to be in violation of that agreement? $?^{136}$ Might the award mean that the flag state, if a party to the agreement, may not be able to contest that action under the compulsory jurisdiction provisions of the LOS Convention? ${ }^{137}$ If compulsory jurisdiction over high seas fishing was included in the LOS Convention to protect and balance the interests of both distant-water fishing states and coastal states in both freedom of fishing and conservation, why should regional fisheries agreements that presumably have the same goal be interpreted to permit judicial protection of one but not the other? For how long would governments tolerate a system in which courts did so? Is it better for courts to protect neither the right to fish nor the duty to conserve on the high seas than to protect both? Which approach better promotes stability in the law of the sea?

Japanese fishing was subject to the limitations specified in the ITLOS provisional measures order for a year. Japan also made concessions to Australia and New Zealand that narrowed

19 The new Western and Central Pacific Agreement regarding highly migratory stocks expressly incorporates the dispute settlement provisions of the Straddling Stocks Agreement. See discussion infra at notes 140, 142.

${ }^{135}$ Immediately before the dispositif, the award states:

Finally, the Tribunal observes that, when it comes into force, the [Straddling Stocks Agreement] ... should, for States Parties to it, not only go far towards resolving procedural problems that have come before this Tribunal but, if the Convention is faithfully and effectively implemented, ameliorate the substantive problems that have divided the Parties. The substantive provisions of the Straddling Stocks Agreement are more detailed and far-reaching than the pertinent provisions of UNCLOS or even of the CCSBT.

The tribunal then paraphrases the dispute settlement provisions (quoted supra note 78) applying Part XV of the LOS Convention to both the Straddling Stocks Agreement and other agreements relating to straddling fish stocks and highly migratory fish stocks. Award, supra note 15, para. 71.

The award does not advert to the potential problem posed by the 1993 FAO compliance agreement. That agreement was designed to strengthen enforcement of the high seas conservation obligations arising under the LOS Convention by elaborating on flag state duties and restricting the reflagging of noncomplying fishingvessels. Like the Straddling Stocks Agreement, its conclusion was called for by Agenda 21 of the 1992 UNCED. Unlike the Straddling Stocks Agreement, it does not provide for compulsory jurisdiction; its dispute settlement clauses (Article IX) closely resemble those of Article 16 of the CSBT Convention. Does the SBT award mean that a general agreement designed to strengthen enforcement of the conservation regime of the LOS Convention in fact weakens enforcement of that regime because it contains an implied covenant not to sue under the LOS Convention? SeeAgreement to Promote Compliance with International Conservation and Management Measures by Fishing Vessels on the High Seas, Nov. 23, 1993, in FoOD AND AGRICULTURE ORGANIZATIONAND DIVISIONOF OCEAN AFFAIRS AND THE LAW OF THE SEA, UNITED NATIONS, INTERNATIONAL FISHERIES INSTRUMENTS WITH INDEX 41, UN Sales No. E.98.V.11 (1998).

${ }^{156}$ Spain was not successful in attempting to persuade the ICJ to exclude arrest of a fishing vessel on the high seas from Canada's reservation to compulsoryjurisdiction regarding "disputes arising out of or concerning conservation and management measures taken by Canada with respect to vessels fishing in the NAFO Regulatory Area, as defined in the Convention on Future Multilateral Cooperation in the Northwest Atlantic Fisheries, 1978, and the enforcement of such measures." Fisheries Jurisdiction (Spain v. Can.), Jurisdiction, 1998 ICJ REP. 432 (Dec. 4).

${ }^{137}$ The substantive and enforcement provisions of the Straddling Stocks Agreement may increase the importance of this question. This is an additional reason for concluding that the award is generally not applicable to fisheries agreements regarding straddling stocks and highly migratory stocks concluded by parties to the Straddling Stocks Agreement. See supra notes 129-35 and corresponding text. 
the gap between them. The arbitral award, in unusually explicit language, suggests that, although the provisional measures order would necessarily no longer be in effect, an attempt to return to the status quo prior to the issuance of that order would constitute an aggravation of the dispute. ${ }^{138}$ This raises particularly interesting questions about the relative costs and benefits of the award to Japan.

The award may already have had a negative impact on Japanese fishing interests. Exactly one month after the award, following years of negotiation under a chairman with a remarkable record of success at achieving accommodation and consensus in difficult law of the sea negotiations, ${ }^{139}$ on September 4, 2000, a new multilateral Convention on the Conservation and Management of Highly Migratory Fish Stocks in the Western and Central Pacific Ocean was adopted over Japan's negative vote at the concluding session of a widely attended regional conference in Honolulu. ${ }^{140}$ The likelihood that many participants, quite apart from Australia and New Zealand, were happy about the arbitral award is slim. Some also perceived a hardening of Japanese positions at the concluding session. ${ }^{141}$ Be that as it may, Article 31 of the new regional convention they adopted expressly incorporates the dispute settlement provisions of the Straddling Stocks Agreement, which in turn incorporates the dispute settlement provisions of the LOS Convention. ${ }^{142}$

Regional fisheries negotiations in the last few years make clear that the Straddling Stocks Agreement provides the only widely acceptable blueprint for promoting stability in high seas fisheries relations, which in turn significantly affects stability in the law of the sea in general. The Agreement consciously uses compulsory jurisdiction as a common refuge from the storm of disagreement. One would think Japanese fishing interests in particular might have benefited from an award that gently eased the way in.

\section{DAMAGE CONTROL}

What if the foregoing analysis is at least partly correct? What might Japan and other states do to limit the potentially adverse affects of the award? Three things that might be done can reasonably be viewed as consistent with the award. If enough governments take such steps, the influence on future cases is likely to be decisive, and the problem of precedent contained.

- States could effectively overrule the result with respect to fisheries matters-as the arbitral tribunal itself apparently acknowledged — by ratifying the Straddling Stocks Agreement and encouraging others to join them by becoming party to both the

\footnotetext{
${ }^{138}$ Award, supra note 15, paras. 67-70. The possible implication is that the duty not to aggravate or extend a dispute, typically invoked in provisional measures orders, is relevant, at least in some circumstances, even when the dispute is not pending before a tribunal.

${ }^{139}$ The chairman, Ambassador Satya N. Nandan, was rapporteur of the Second Committee throughout the Third UN Conference on the Law of the Sea and chaired important informal negotiations at the conference. He subsequently headed the UN law of the sea office, chaired the negotiations for both the Agreement Implementing Part XI of the LOS Convention and the Straddling Stocks Agreement, and is currently secretary-general of the International Seabed Authority.

140 "The result of the vote was 19 in favour, 2 against (Japan and Republic of Korea), with three abstentions (China, France and Tonga)." Multilateral High-Level Conference on the Conservation and Management of Highly Migratory Fish Stocks in the Western and Central Pacific, Final Act n.7 (Sept. 5, 2000) (on file with author), at $<$ http://www.oceanlaw.net/texts/index.htm> (note 7 is notincluded in the Web version). The Japanese representative did not sign the final act. Political concerns regarding the provisions dealing with the participation of Taiwan and French overseas territories, respectively, may have prompted the abstentions of China and France.

${ }^{141}$ This may not be the kind of effect the arbitral tribunal expected. See text at notes 138 supra and 149 infra.

${ }^{142}$ See supra note 78. There is an exception in Annex $\mathrm{I}$, paragraph 3 of the new convention on the western and central Pacific, supra note 140: disputes with a "fishing entity" (a reference to Taiwan) "shall, at the request of either party to the dispute, be submitted to final and binding arbitration in accordance with the relevant rules of the Permanent Court of Arbitration."
} 
Agreement and the LOS Convention. ${ }^{143}$ The arbitral tribunal itself appears to have regarded this as a positive development. ${ }^{144}$

- With respect to matters other than fisheries, it could help to instill a sense of caution in applying the award if governments made clear that the award is not in their view necessarily relevant to the relationship between other agreements and the compulsory jurisdiction provisions of the LOS Convention or other treaties.

- Finally, governments might declare that, absent an express provision, they do not generally regard the presence, in treaties to which they are party, of dispute settlement clauses that do not establish compulsory jurisdiction as excluding compulsory jurisdiction under the LOS Convention or other treaties. Such declarations would place the burden on the party advocating an implied exclusion of compulsory jurisdiction.

Cautious governments often prefer to say nothing until a specific issue arises. The purpose is presumably to keep options open. Silence, however, risks a broad interpretation of the precedential effect of the award, which could prejudice interests not only in the compulsoryjurisdiction provisions of the Law of the Sea Convention, butalso in comparable provisions of other treaties. It also overlooks the fact that drafting decisions need to be made regarding compromissory clauses in new treaties. These problems are not likely to disappear on their own.

\section{CONCLUSION: HARMONIZING THE MODELS}

If the political process seriously deadlocks, arbitrators and adjudicators may be called upon under the LOS Convention to act in some measure as conservators of last resort. ${ }^{145}$ The underlying questions of whether and when a tribunal should intervene as conservator of last resort are important. The award suggests that the arbitral tribunal did not exclude such a role, but discerned no need for it in the $S B T$ case. ${ }^{146}$

While the conclusion that a tribunal has some role as conservator largely derives from the substantive model of the LOS Convention, the suggestion that the role is assumed as a last resort largely derives from the procedural model. The former emphasizes the need to ensure compliance with the conservation and environmental norms of the Convention; the latter emphasizes circumspection in displacing the political process, and eschews the role of continuing alternative manager of the scientific and technical issues and allocation quarrels that

${ }^{1+3}$ See supra notes 129-35 and corresponding text. Still, cases have a way of surviving treaties that alter their precise holdings. The mystique of Lotus persists notwithstanding the reversal suffered by its holding in Article 11 of the 1958 Convention on the High Seas (repeated in Article 97 of the LOS Convention).

${ }^{144}$ See supra note 135.

${ }^{145}$ The term is mine. The argument in support of such a role for arbitrators and adjudicators is substantially strengthened by the dispute settlement provisions (Arts. 27-32) of the Straddling Stocks Agreement, supra note 53. Articles 7(5), 16(2), and 31(2) regarding provisional measures contemplate the need "to prevent damage to the stocks in question." Article 30 , paragraph 5 provides:

Any court or tribunal to which a dispute has been submitted under this Part shall apply the relevant provisions of the [LOS] Convention, of this Agreement and of any relevant subregional, regional or global fisheries agreement, as well as generally accepted standards for the conservation and management of living marine resources and other rules of international law not incompatible with the Convention, with a view to ensuring the conservation of the straddling fish stocks and highly migratory fish stocks concerned.

${ }^{146}$ This conclusion appears to be the import of the observation regarding Article 300 of the LOS Convention concerning good faith and abuse of rights:

The Tribunal does not exclude the possibility that there might be instances in which the conduct of a State Party to UNCLOS and to a fisheries treaty implementing it would be so egregious, and risk consequences of such gravity, that a Tribunal might find that the obligations of UNCLOS provide a basis for jurisdiction, having particular regard to the provisions of Article 300 of UNCLOS. While Australia and New Zealand in the proceedings before ITLOS invoked Article 300, in the proceedings before this Tribunal they made clear that they do not hold Japan to any independent breach of an obligation to act in good faith.

Award, supra note 15 , para. 64. 
typically plague conservation negotiations. Harmonizing the two requires a subtle appreciation of the circumstances concerned.

An urgent need for intervention is itself a requirement for provisional measures. ${ }^{147}$ Moreover, the risk of rapid imposition of provisional measures may encourage self-restraint and negotiation. ${ }^{148}$ On the other hand, progress in narrowing the dispute following a provisional measures order may occur in the often substantial period required for preparation of the parties' memorials on the merits. The difficulty in fashioning final conservation judgments of indefinite duration at the merits stage, and the likelihood that a tribunal may be asked thereafter to address disputes regarding the judgment or changes in circumstances, accentuates the problem of interfering with the political process in the long term. Accordingly, the same measure of caution appropriate at the merits stage may not be appropriate at the provisional measures stage.

Without regard to the precise legal grounds invoked for dismissal in the SBT award (which could exclude the same pattern in a future case), if one focuses only on the result, there is something to be said for the message sent by the combined actions of the two tribunals in the case: where conservation is at risk, the parties will be placed under the supervision of a binding provisional measures order that is likely to restrain fishing for at least one season; this will be done on the understanding that, if the parties show significant progress in resolving matters on their own, the tribunal may withdraw from the matter by the time it is ready to decide preliminary objections or other issues on the merits; this, in turn, will be done on the understanding that the parties continue to make progress and do not revert to the status quo ante. ${ }^{149}$ The legal justification for such an approach is that the tribunals are seeking to enforce both the substantive norms of the Convention (conservation and management) and its procedural allocations of primary responsibility for achieving those goals (adoption of conservation and management measures through arrangements or organizations established by the states concerned).

Whether a jurisdictional approach in general, and the good faith and abuse-of-right provisions of Article 300 in particular, are the most appropriate bases for deciding when a conservation dispute is ripe for adjudication is a different matter. ${ }^{150}$ The implication that disputes excluded from compulsory jurisdiction can be heard as cases about good faith and abuse of right may in itself be regarded as a troubling departure from the procedural model. There is reason for concern even if (as seems plausible) the implication does not extend to the exceptions to compulsory jurisdiction contained in section 3 of Part XV.

The reference in the award ${ }^{151}$ to the risk of grave consequences as a justification for judicial intervention on the merits can be understood to reflect something of the alternative standard for provisional measures set forth in Article 290(1) of the LOS Convention, which permits judicial intervention "to prevent serious harm to the marine environment." 152 The underlying justification for judicial intervention on the merits may be found in the fact that a negotiating deadlock among the parties allows unrestrained (or under-restrained) activities to continue that seriously implicate conservation and environmental duties owed to the international community as a whole (or at least to all parties to the LOS Convention). ${ }^{153}$ The issue would be neither jurisdiction as such nor egregious conduct as such, but ripeness

\footnotetext{
${ }^{147}$ See supra note 26.

${ }^{148}$ The possibility of provisional measures is adverted to at several points in the Straddling Stocks Agreement, suggesting perhaps a greater expectation of intervention. See supra note 145.

${ }_{149}$ See Award, supra note 15, paras. 67-70.

${ }^{150}$ See supra note 146.

${ }^{151} I d$.

${ }^{152}$ See supra note 29.

${ }^{153}$ The analogy in municipal law might be public interest or ordre public. Because the underlying substantive objectives are stated in the Convention, and the article on provisional measures makes clear that judges and arbitrators are expected to implement them, I do not believe it necessary to reach further for a general theory of public-interest norms in international law to justify such an approach.
} 
measured by an objective standard that focuses on the likelihood of continuing deadlock and the gravity of the risks posed to the environment by the respondent's alleged breach of conservation and management obligations.

If all that was decided in fact in the $S B T$ arbitration is that the dispute had not yet passed a threshold at which the failure to reach agreement under the CSBT Convention was deemed likely to seriously prejudice conservation and environmental obligations under the LOS Convention, then one might form a different understanding of the award. Among other things, it would become possible that the arbitral tribunal, notwithstanding its statements to the contrary, did not entirely reject the argument that there was as yet no dispute ripe for adjudication on the merits, particularly in light of the narrowing of differences and other progress the tribunal pointedly noted had been made since the provisional measures order a year earlier. From this perspective, all it would really have decided is that it was not yet appropriate to step in as conservator of last resort.

Whether the arbitrators envisaged such an interpretation is not the question. Lawyers and judges look for those elements of the accumulated learning in the law, including precedent, that help in arriving at a reasonable resolution of the problem before them, and that point to a desirable evolution of our understanding of the law and its administration.

If there is an alternative that emphasizes harmonization of political and judicial settlement of disputes in the context of fisheries conservation, that alternative may have broader application. An emphasis on harmonization reflects the underlying view that, absent an express indication of a contrary intent, one should attempt to give effect to all of the agreements of the parties by first inquiring whether it is possible to reconcile them. The effort that judges might expend on resolving a conflict between different dispute settlement clauses might better be expended on finding ways to avoid that conflict by harmonizing the dispute settlement clauses.

One possibility is to establish a temporal relationship between different dispute settlement clauses that reflects the underlying view that, where reasonably foreseeable, voluntary resolution of disputes is to be preferred. The ripeness test for adjudication on the merits (but not necessarily for provisional measures) would be the plausible likelihood of voluntary resolution of the dispute in a reasonable time under the procedures contemplated by the agreement that does not provide for compulsory jurisdiction. This test is different from a jurisdictional requirement that good faith efforts to achieve a voluntary settlement have failed. A regime-building conception rooted in the treaty that provides for compulsoryjurisdiction would inform the question of jurisdiction as such - that is, whether a tribunal has the authority to prescribe provisional measures or decide the merits-but there could be significant deference to a Westphalian conception in determining when a tribunal would actually proceed to adjudicate and decide the merits.

There are doubtless other possibilities for harmonization both of the different dispute settlement clauses and of the contrasting Westphalian and regime-building conceptions. They depend largely on the particular treaties and issues involved. Some characteristics, however, are common to any approach that emphasizes harmonization. At least four merit particular attention.

- First, there is no presumption a priori for or against compulsory jurisdiction. Neither the Westphalian conception nor the regime-building conception is necessarily dominant.

- Second, so long as harmonization is possible, the issue is not jurisdiction as such or admissibility of the claim in the abstract. For example, a tribunal could retain jurisdiction while declining to adjudicate the merits for the time being in light of the agreement of the parties regarding alternative procedures. Among other things, this possibility means that the standards for provisional measures would not be affected; in particular, prima facie jurisdiction would persist. 
- Third, the textbook maxims for determining which legal instrument prevails in the event of a conflict would be irrelevant to the extent that harmonization could be effected.

- Fourth, even if harmonization of the dispute settlement clauses proves impossible, harmonization with the object and purpose of the relevant substantive regimes remains possible. Pursuant to the basic rule that terms are to be understood in the context of the instrument as a whole, primary emphasis in determining whether jurisdiction exists should be given to the underlying relationship between compulsory jurisdiction and the object and operation of the underlying substantive regimes. Mechanical application of the later-in-time maxim, the maxim that the specific governs the general, or other maxims should be avoided, especially when the practical effect of their application is to create a presumption against compulsory jurisdiction established by long-term global regimes.

An attempt simultaneously to apply widely different conceptions of the nature of the international legal system to the resolution of an issue may seem less orderly than some might wish. But the vision of law as a largely autonomous order is itself contested. Both the Westphalian conception and the regime-building conception now influence the expectations of governments and other constituencies of international law. If compulsory jurisdiction is peripheral to the former conception, it is undoubtedly more central to the latter.

The reality is that we find ourselves in an international legal system in transition. The death of the state pronounced by some free market and globalization theorists at the end of the twentieth century is, to recall Mark Twain's turn of phrase, likely to prove as much of an exaggeration as the comparable predictions by Karl Marx in the previous century. ${ }^{154}$ Nevertheless, this period has witnessed increasing legal and practical constraints on unilateral action as the principal means for encouraging compliance with international legal obligations, including restraints on the use of force and on interference with trade and communications. These restraints are especially relevant to the enforcement of obligations with respect to activities beyond the aggrieved state's jurisdiction. If the Westphalian conception relies upon the freedom of a state to take action to protect its interests as a principal law enforcement mechanism, that very conception may suggest that, to the extent such freedom of action is limited, the system may be unable to bear the weight of accumulated grievances unless alternative means are devised to achieve the same ends. The right to sue is one such alternative. From this perspective, a presumption against compulsory jurisdiction-whether rooted in the Westphalian origins of modern international law or in the maxims of the law of treaties-would seem to be in tension, in the most fundamental sense, with the goals not only of the United Nations Charter, but of the open system of trade and communications promoted by some of the most widely accepted regime-building treaties in the world, including the WTO agreements as well as the LOS and ICAO Conventions and related instruments.

The Westphalian and regime-building models do not necessarily and inevitably contradict one another if the role of compulsoryjurisdiction in relation to both is carefully considered. At least for the time being, one of the most significant contributions courts can make may be to find areas of confluence and accommodation between the two conceptions of the international order during the foreseeably substantial period in which neither can be ignored. Reconciliation of the tensions between the values that guide us is one of the important things we ask of law and legal process.

\footnotetext{
${ }^{154}$ In considering this issue in the context of regional integration, we must be cautious not to confuse the region with the world. Not only empires, but federal or otherwise decentralized entities of continental proportions are hardly unknown to the state system. The relationship between continental entities imagined in George Orwell's 1984 was decidedly Westphalian in the worst sense.
} 